\title{
Probe-Dependent Negative Allosteric Modulators of the Long-Chain Free Fatty Acid Receptor FFA4
}

\author{
Kenneth R. Watterson, Steffen V. F. Hansen, Brian D. Hudson, Elisa Alvarez-Curto, \\ Sheikh Zahir Raihan, Carlos M. G. Azevedo, Gabriel Martin, Julia Dunlop, \\ Stephen J. Yarwood, Trond Ulven, and Graeme Milligan
}

Centre for Translational Pharmacology, Institute of Molecular, Cell and Systems Biology, College of Medical, Veterinary and Life Sciences, University of Glasgow, Glasgow, United Kingdom (K.R.W., B.D.H., E.A.-C., S.Z.R., J.D., S.J.Y., G.M.); Department of Physics, Chemistry and Pharmacy, University of Southern Denmark, Odense, Denmark (S.V.F.H., C.M.G.A., G.M., T.U.); and Institute of Biological Chemistry, Biophysics and Bioengineering, School of Engineering and Physical Sciences, Heriot-Watt University, Edinburgh, United Kingdom (S.J.Y.)

Received December 9, 2016; accepted March 29, 2017

\section{ABSTRACT}

High-affinity and selective antagonists that are able to block the actions of both endogenous and synthetic agonists of $\mathrm{G}$ proteincoupled receptors are integral to analysis of receptor function and to support suggestions of therapeutic potential. Although there is great interest in the potential of free fatty acid receptor 4 (FFA4) as a novel therapeutic target for the treatment of type II diabetes, the broad distribution pattern of this receptor suggests it may play a range of roles beyond glucose homeostasis in different cells and tissues. To date, a single molecule, 4-methyl$\mathrm{N}-9 \mathrm{H}$-xanthen-9-yl-benzenesulfonamide $(\mathrm{AH}-7614)$, has been described as an FFA4 antagonist; however, its mechanism of antagonism remains unknown. We synthesized $\mathrm{AH}-7614$ and a chemical derivative and demonstrated these to be negative allosteric modulators (NAMs) of FFA4. Although these NAMs did inhibit FFA4 signaling induced by a range of endogenous and synthetic agonists, clear agonist probe dependence in the nature of allosteric modulation was apparent. Although $\mathrm{AH}-7614$ did not antagonize the second long-chain free fatty acid receptor, free fatty acid receptor 1 , the simple chemical structure of $\mathrm{AH}-7614$ containing features found in many anticancer drugs suggests that a novel close chemical analog of $\mathrm{AH}-7614$ devoid of FFA4 activity, 4-methyl- $N$-(9H-xanthen-9-yl)benzamide (TUG-1387), will also provide a useful control compound for future studies assessing FFA4 function. Using TUG-1387 alongside $\mathrm{AH}-7614$, we show that endogenous activation of FFA4 expressed by murine $\mathrm{C} 3 \mathrm{H} 10 \mathrm{~T} 1 / 2$ mesenchymal stem cells is required for induced differentiation of these cells toward a more mature, adipocyte-like phenotype.

\section{Introduction}

Free fatty acid receptor 4 (FFA4) (Davenport et al., 2013; Milligan et al., 2017), which is also still frequently designated as GPR120 (Hirasawa et al., 2005), was identified in 2005 as a $\mathrm{G}$ protein-coupled receptor (GPCR) responsive to long-chain free fatty acids (Hirasawa et al., 2005). Since then, not least because essential and other polyunsaturated $\omega-3$ fatty acids

These studies were supported by the Biotechnology and Biological Sciences Research Council [Grant BB/K019864/1] and the Danish Council for Strategic Research [Grant 11-116196]. B.D.H., G.M., and T.U. are shareholders in Caldan Therapeutics.

https://doi.org/10.1124/mol.116.107821. with health-promoting properties are among the most potent fatty acid activators of this receptor (Hirasawa et al., 2005; Christiansen et al., 2015), there has been strong interest in better understanding the biologic functions of FFA4 and in its potential as a therapeutic target (Liu et al., 2015; Li et al., 2016). Because reported effects of FFA4 activation include regulation of glucose homeostasis (Oh et al., 2014; Azevedo et al., 2016), regulation of release of incretins and satiety-regulating hormones (Hirasawa et al., 2005), modulation of insulin sensitivity (Oh et al., 2010, 2014; Azevedo et al., 2016), and potential effects on weight gain (Ichimura et al., 2012; Mo et al., 2013; Azevedo et al., 2016), a large focus of studies on FFA4 has centered

ABBREVIATIONS: AH-7614, 4-methyl- $N-9 H$-xanthen-9-yl-benzenesulfonamide; aLA, $\alpha$ linolenic acid; BRET, bioluminescence resonance energy transfer; Cpd A, 3-[2-chloro-5-(trifluoromethoxy)phenyl]-3-azaspiro[5.5]undecane-9-acetic acid; $d_{6}$-DMSO, $d_{6}$-dimethylsulfoxide; DMEM, Dulbecco's modified Eagle's medium; ESI-HRMS, electrospray ionization-high-resolution mass spectrometry; eYFP, enhanced yellow fluorescent protein; FBS, fetal bovine serum; FFA1, free fatty acid receptor 1; FFA4, free fatty acid receptor 4; GPCR, G protein-coupled receptor; GSK137647A, 4-methoxy-N-(2,4,6trimethylphenyl)-benzenesulfonamide; HBSS, Hanks' balanced salt solution; hFFA1, human FFA1; hFFA4, human FFA4; HPLC, high-performance liquid chromatography; IBMX, 3-isobutyl-1-methylxanthine; IID, $100 \mathrm{nM}$ insulin, $500 \mathrm{mM}$ 3-isobutyl-1-methylxanthine and $10 \mathrm{nM}$ dexamethasone; mFFA4, murine FFA4; mp, melting point; NAM, negative allosteric modulator; pIC $_{50}$, negative logarithm of IC50; PPAR $\gamma$, peroxisome proliferator activator receptor $\gamma$; RT-qPCR, reverse-transcription quantitative polymerase chain reaction; TUG-1197, 2-(3-(pyridin-2-yloxy)phenyl)-2,3-dihydrobenzo[d]isothiazole 1,1-dioxide; TUG-1387, 4-methyl-N-(9H-xanthen-9-yl)benzamide; TUG-1506, 4-methyl-N-(9H-thioxanthen-9-yl)benzenesulfonamide; TUG-770, 4-[2-[2(cyanomethyl)phenyl]ethynyl]-2-fluorobenzenepropanoic acid; TUG-891, 4-[(4-fluoro-4'-methyl[1,1'-biphenyl]-2-yl)methoxy]-benzenepropanoic acid. 
on the possibility that agonists of this receptor might be useful antidiabetic agents (Cornall et al., 2014; Zhang and Leung, 2014; Moran et al., 2016). However, it is clear that the expression pattern of FFA4, which includes high levels in the lung, in macrophage populations, and in various cancer cell types (Houthuijzen, 2016; Milligan et al., 2017), indicates a broader set of roles and potential for therapeutic interventions targeting this receptor (Milligan et al., 2017). This has resulted in screening for, and the identification of, a number of series of FFA4 agonist ligands (Milligan et al., 2015,2017 ), although chemical diversity within these series has, until recently (e.g., Sparks et al., 2014; Azevedo et al., 2016), remained rather limited and based on carboxylatecontaining ligands that resemble synthetic fatty acids. FFA4 has been shown to be a potential regulator of adipocyte development and differentiation (Gotoh et al., 2007), potentially via increasing expression of the adipogenic transcription factor peroxisome proliferator activator receptor $\gamma$ (PPAR $\gamma$ ) (Hasan et al., 2015; Song et al., 2016). Moreover, adipocyte differentiation from bone marrow mesenchymal stem cells has also been suggested to be promoted by FFA4 (Gao et al., 2015).

A major challenge in studying all aspects of both in vivo and ex vivo regulation of cell and tissue function by FFA4 is that the endogenous fatty acid ligands that are able to activate the receptor are present ubiquitously. Furthermore, being bound extensively by plasma proteins, the concentrations and disposition of "free" fatty acids are often challenging to define (Ulven and Christiansen, 2015), as is the extent of receptor activation in situ that can be attributed to such systemic, circulating fatty acids. As such, alongside various "knockdown" and "knockout" strategies (Alvarez-Curto et al., 2016), well characterized and selective blockers of FFA4 function would be highly valuable tool compounds to further unravel biologic roles of FFA4. To date, a single FFA4 "antagonist" has been described. Compound 39 (Sparks et al., 2014) [now designated AH-7614 (4-methyl- $N$-9H-xanthen-9yl-benzenesulfonamide) by commercial vendors] was shown to block effects of both a fatty acid and a synthetic FFA4 agonist in FFA4-transfected U2OS human osteosarcoma cells, and to antagonize both FFA4-mediated insulin secretion from mouse insulinoma MIN6 cells and the secretion of GLP-1 from the human intestinal cell line NCI-H716 (Sparks et al., 2014).

Herein, we examine the antagonistic properties of AH-7614, and a small number of chemical derivatives, at FFA4. This demonstrates that $\mathrm{AH}-7614$ is able to inhibit FFA4-mediated signals induced by a range of distinct fatty acids and synthetic FFA4 agonist ligands across all endpoints tested. Analysis of the mechanism of antagonism indicates that these compounds are negative allosteric modulators (NAMs) of FFA4 function, which display "probe dependence" in the nature of their inhibitory properties, depending on the specific agonists they are inhibiting. This work also identifies a close chemical derivative of $\mathrm{AH}-7614$ that lacks antagonistic activity at FFA4, which, given the current lack of knowledge about potential off-target effects of AH-7614, will be a useful tool in defining FFA4-specific biologic effects. We have demonstrated the utility of this approach in assessing the role of FFA4 in adipogenesis of murine C3H10T1/2 mesenchymal stem cells.

\section{Materials and Methods}

Materials and Compounds. Unless otherwise stated, all biochemicals and reagents were from Sigma-Aldrich (St. Louis, MO). Tissue culture reagents and buffers were from Life Technologies Inc (Paisley, UK). TUG-891 [4-[(4-fluoro-4'-methyl[1,1'-biphenyl]-2-yl)methoxy]-benzenepropanoic acid] was synthesized as described previously (Shimpukade et al., 2012). Compound 34 (TUG-1197) (2-(3-(pyridin-2-yloxy)phenyl)-2,3-dihydrobenzo[d]isothiazole 1,1-dioxide) was synthesized as described by Azevedo et al. (2016). GSK137647A [4-methoxy- $N$-(2,4,6-trimethylphenyl)-benzenesulfonamide] was synthesized according to Sparks et al. (2014). TUG-770 (4-[2-[2-(cyanomethyl)phenyl]ethynyl]-2-fluorobenzenepropanoic acid) was synthesized as described previously (Christiansen et al., 2013). Cpd A (3-[2-chloro-5(trifluoromethoxy)phenyl]-3-azaspiro[5.5]undecane-9-acetic acid) was synthesized essentially as described by Chelliah et al. (2014). AH-7614/ compound 39 was synthesized as follows: xanthone $(100 \mathrm{mg}, 0.5 \mathrm{mmol})$ was dissolved in methanol ( $10 \mathrm{ml})$, sodium borohydride $(96 \mathrm{mg}, 2.6 \mathrm{mmol})$ was added portionwise over 20 minutes, and the reaction was stirred at room temperature for 24 hours. The reaction was partitioned between ethyl acetate and water. The two phases were separated, and the aqueous phase was extracted twice with ethyl acetate. The organic phases were combined, washed with brine, dried over anhydrous sodium sulfate, filtered, and concentrated. The crude product was used directly in the next step without further purification. $p$-Toluenesulfonamide (95 $\mathrm{mg}, 0.56 \mathrm{mmol}$ ) was added to the crude mixture, followed by acetic acid $(5 \mathrm{ml})$. The reaction was stirred for 2 hours at room temperature. The reaction was partitioned between water and ethyl acetate. The two phases were separated, and the aqueous phase was extracted twice with ethyl acetate. The organic phases were combined, washed with brine, dried over anhydrous sodium sulfate, filtered, and concentrated. The crude product was purified by silica gel flash chromatography (ethyl acetate/petroleum ether, 1:4) to give the desired compound as a white solid (136 mg, $77 \%$ over two steps): $\mathrm{mp} 194.1-195.5^{\circ} \mathrm{C} ;{ }^{1} \mathrm{H}$ NMR $\left(400 \mathrm{MHz} \mathrm{CDCl}_{3}\right) 7.83-7.75(\mathrm{~m}, 2 \mathrm{H}), 7.33(\mathrm{~d}, J=8.0 \mathrm{~Hz}, 2 \mathrm{H}), 7.30$ $7.23(\mathrm{~m}, 2 \mathrm{H}), 7.15(\mathrm{dd}, J=7.8,1.4 \mathrm{~Hz}, 2 \mathrm{H}), 7.08(\mathrm{dd}, J=8.3,1.0 \mathrm{~Hz}, 2 \mathrm{H})$, $6.99(\mathrm{td}, J=7.7,1.2 \mathrm{~Hz}, 2 \mathrm{H}), 5.77(\mathrm{~d}, J=8.6 \mathrm{~Hz}, 1 \mathrm{H}), 4.91(\mathrm{~d}, J=8.6 \mathrm{~Hz}$, $1 \mathrm{H}), 2.47(\mathrm{~s}, 3 \mathrm{H}) ;{ }^{13} \mathrm{C} \mathrm{NMR}\left(100 \mathrm{MHz}, \mathrm{CDCl}_{3}\right): 151.3,143.6,138.6,129.8$, $129.5,127.2,123.6,120.4,116.7,49.2,21.6$; electrospray ionizationhigh-resolution mass spectrometry (ESI-HRMS) $\mathrm{m} / z$ : calculated $\mathrm{C}_{20} \mathrm{H}_{17} \mathrm{NaO}_{3} \mathrm{~S}\left[\mathrm{M}+\mathrm{Na}^{+}\right.$]: 374.0821; found: 374.0804; high-performance liquid chromatography (HPLC) $99.7 \%$. The data agree with those of Liu et al. (2013). TUG-1387 [4-methyl- $N$-(9H-xanthen-9-yl)benzamide] was synthesized as follows: 4-Methylbenzamide $(205 \mathrm{mg}, 1.5 \mathrm{mmol})$ and $9 H$ xanthen-9-ol (150 mg, $0.76 \mathrm{mmol})$ were suspended in acetic acid $(1.5 \mathrm{ml})$ and heated to $90^{\circ} \mathrm{C}$. The compounds went into solution after 1 minute, and a few minutes later, a white solid started to precipitate. The reaction was heated overnight and cooled to room temperature, filtered and washed with acetic acid $(0.5 \mathrm{ml})$, then washed with cold ethyl acetate $(3 \mathrm{ml})$. Subsequent drying gave the product as a white solid $(180 \mathrm{mg}$, 75\%): $\mathrm{mp} 229.8-231.6^{\circ} \mathrm{C} ; t_{\mathrm{R}}=12.88$ minutes (HPLC purity: $98.7 \%$ ); ${ }^{1} \mathrm{H}$ NMR $\left[400 \mathrm{MHz}, d_{6}\right.$-dimethylsulfoxide $\left(d_{6}\right.$-DMSO)] $\delta 9.36(\mathrm{~d}, J=$ $8.6 \mathrm{~Hz}, 1 \mathrm{H}), 7.82(\mathrm{~d}, J=8.2 \mathrm{~Hz}, 1 \mathrm{H}), 7.40(\mathrm{~d}, J=7.6 \mathrm{~Hz}, 1 \mathrm{H}), 7.37-7.31$ (m, $1 \mathrm{H}), 7.26(\mathrm{~d}, J=8.0 \mathrm{~Hz}, 1 \mathrm{H}), 7.20-7.11(\mathrm{~m}, 1 \mathrm{H}), 6.55(\mathrm{~d}, J=8.6 \mathrm{~Hz}$, $1 \mathrm{H}), 2.34(\mathrm{~s}, 1 \mathrm{H}) ;{ }^{13} \mathrm{C} \mathrm{NMR}\left(101 \mathrm{MHz}, d_{6}\right.$-DMSO) $\delta 165.7,150.6,141.3$, 131.1, 130.0, 128.9, 128.8, 127.5, 123.4, 121.9, 116.1, 43.0, 20.9; ESI-HRMS calculated for $\mathrm{C}_{21} \mathrm{H}_{17} \mathrm{NnaO}_{2}\left[\mathrm{M}+\mathrm{Na}^{+}\right]$: 338.1151, found: 338.1163. The data agree with those of Patrick and Dolan (1973). TUG-1506 (4-methyl$\mathrm{N}$-(9H-thioxanthen-9-yl)benzenesulfonamide) was synthesized as follows: A 250-ml flask was charged with thioxanthone $(2.0 \mathrm{~g}, 9.4 \mathrm{mmol})$, tetrahydrofuran $(30 \mathrm{ml})$, and methanol $(10 \mathrm{ml})$. The solution was stirred at room temperature, and $\mathrm{NaBH}_{4}(1.07 \mathrm{~g}, 28.3 \mathrm{mmol})$ was added slowly. The initially yellow reaction mixture slowly turned orange. After 45 minutes, the solution was diluted with water and extracted three times with ethyl acetate. The combined organic phases were washed with brine, dried over sodium sulfate, and concentrated to give the crude alcohol as an orange solid ( $2.02 \mathrm{~g})$ that was used immediately in the next step: ${ }^{1} \mathrm{H}$ NMR (400 MHz, $d_{6}$-DMSO) $\delta 7.70$ (d, $J=7.6 \mathrm{~Hz}, 2 \mathrm{H}$ ), 7.50 (dd, 
$J=7.7,0.9 \mathrm{~Hz}, 2 \mathrm{H}), 7.36(\mathrm{td}, J=7.5,1.2 \mathrm{~Hz}, 2 \mathrm{H}), 7.28(\mathrm{td}, J=7.5$, $1.0 \mathrm{~Hz}, 2 \mathrm{H}), 6.40(\mathrm{~d}, J=5.8 \mathrm{~Hz}, 1 \mathrm{H}), 5.19(\mathrm{~d}, J=5.7 \mathrm{~Hz}, 1 \mathrm{H}) ;{ }^{13} \mathrm{C} \mathrm{NMR}$ $\left(101 \mathrm{MHz}, d_{6}\right.$-DMSO) $\delta 139.0,130.8,126.8,126.6,126.4,125.3,69.3$. The data agree with those of Cozzi and Zoli (2008). 9H-Thioxanthen-9-ol (2.02 g, $9.4 \mathrm{mmol})$ and $p$-toluenesulfonamide $(2.22 \mathrm{~g}, 10.4 \mathrm{mmol})$ were dissolved in acetic acid $(30 \mathrm{ml})$ and stirred at room temperature overnight. The resulting precipitate was isolated by filtration and washed first with cold acetic acid and then cold petroleum ether to afford the product as a white solid $(2.2 \mathrm{~g}, 64 \%)$ : $\mathrm{mp} 158.7-163.9^{\circ} \mathrm{C} ; t_{\mathrm{R}}=$ 12.94 minutes (HPLC purity: 99.0\%); $R_{f}=0.40$ (EtOAc:PE, $\left.1: 1\right) ;{ }^{1} \mathrm{H}$ NMR (400 MHz, $d_{6}$-DMSO) $\delta 8.76(\mathrm{~d}, J=8.4 \mathrm{~Hz}, 1 \mathrm{H}), 7.65(\mathrm{~d}, J=8.3 \mathrm{~Hz}$, $2 \mathrm{H}), 7.50-7.46(\mathrm{~m}, 2 \mathrm{H}), 7.37-7.28(\mathrm{~m}, 4 \mathrm{H}), 7.28-7.19(\mathrm{~m}, 4 \mathrm{H}), 5.23(\mathrm{~d}, J=$ $8.4 \mathrm{~Hz}, 1 \mathrm{H}), 2.35(\mathrm{~s}, 3 \mathrm{H}) ;{ }^{13} \mathrm{C}$ NMR $\left(101 \mathrm{MHz}, d_{6}\right.$-DMSO) $\delta 142.4,138.8$, $134.9,132.2$, 129.3, 127.3, 126.8, 126.7, 126.5, 126.3, 56.5, 20.9; ESIHRMS calculated for $\mathrm{C}_{20} \mathrm{H}_{17} \mathrm{NNaO}_{2} \mathrm{~S}_{2}\left[\mathrm{M}+\mathrm{Na}^{+}\right]$: 390.0593 , found: 390.0585. The data agree with those of Tamura et al. (1977).

Cell Culture. HEK293T cells were maintained in Dulbecco's modified Eagle's medium (DMEM) supplemented with $10 \%(\mathrm{v} / \mathrm{v})$ fetal bovine serum (FBS) at $37^{\circ} \mathrm{C}$ and $5 \%(\mathrm{v} / \mathrm{v}) \mathrm{CO}_{2}$. Flp-In T-REx 293 cell lines, generated to inducibly express various tagged versions of human FFA4 (hFFA4), human FFA1 (hFFA1), or murine FFA4 (mFFA4) following treatment with doxycycline, were maintained in DMEM supplemented with $10 \%(\mathrm{v} / \mathrm{v}) \mathrm{FBS}, 100 \mathrm{U} / \mathrm{ml}$ penicillin, $100 \mu \mathrm{g} / \mathrm{ml}$ streptomycin, and $200 \mu \mathrm{g} / \mathrm{ml}$ hygromycin B. Human brain astrocytoma $1321 \mathrm{~N} 1$ cells stably transfected with hFFA1 were grown in DMEM supplemented with $10 \%$ (v/v) FBS, $100 \mathrm{U} / \mathrm{ml}$ penicillin, $100 \mu \mathrm{g} / \mathrm{ml}$ streptomycin, and $400 \mu \mathrm{g} / \mathrm{ml}$ G418. To study adipogenesis, murine C3H10T1/2 cells (Tang et al., 2004) were grown in DMEM containing $10 \%(\mathrm{v} / \mathrm{v}) \mathrm{FBS}, 100 \mathrm{U} / \mathrm{ml}$ penicillin, and $100 \mu \mathrm{g} / \mathrm{ml}$ streptomycin in a $37^{\circ} \mathrm{C}$ incubator with $5 \%(\mathrm{v} / \mathrm{v}) \mathrm{CO}_{2}$. Cells in 10 -cm dishes were differentiated with IID [100 nM insulin, $500 \mu \mathrm{M}$ 3-isobutyl-1-methylxanthine (IBMX), and $10 \mathrm{nM}$ dexamethasone] for 5 days in the presence/ absence of vehicle [0.1\% (v/v) DMSO], $10 \mu \mathrm{M}$ AH-7614, or $10 \mu \mathrm{M}$ TUG-1387.

Plasmids. Plasmids encoding either the human (short isoform) or mouse FFA4 receptors with enhanced yellow fluorescent protein (eYFP) or the related fluorescent protein mVenus fused to their $\mathrm{C}$ terminus and incorporating an N-terminal FLAG epitope tag in the pcDNA5 FRT/TO expression vector were generated as previously described (Hudson et al., 2013; Butcher et al., 2014; Alvarez-Curto et al., 2016; Prihandoko et al., 2016).

$\boldsymbol{\beta}$-Arrestin-2 Interaction Assay. $\beta$-Arrestin- 2 recruitment to either human or mouse isoforms of FFA4 was measured using a bioluminescence resonance energy transfer (BRET)-based approach. HEK293T cells were cotransfected with eYFP-tagged forms of each receptor in a 4:1 ratio with a $\beta$-arrestin-2 Renilla luciferase plasmid using polyethylenimine. Cells were then transferred into white 96 -well plates at 24 hours post-transfection. At 48 hours post-transfection, cells were washed with Hanks' balanced salt solution (HBSS) and then incubated in fresh HBSS prior to the assay. Cells were preincubated for 15 minutes with HBSS supplemented with vehicle [1\% (v/v) DMSO], AH-7614, TUG-1506, or TUG-1387. Cells were incubated with $2.5 \mu \mathrm{M}$ Renilla luciferase substrate coelenterazine $\mathrm{h}$ (Nanolight Tech, Pinetop, CA) at $37^{\circ} \mathrm{C}$ for 10 minutes and then stimulated with various FFA4 agonists for a further 5 minutes at $37^{\circ} \mathrm{C}$. BRET resulting from receptor- $\beta$-arrestin- 2 interaction was then determined by measuring the ratio of luminescence at 535 and $475 \mathrm{~nm}$ using a Pherastar FS fitted with the BRET1 optic module (BMG Labtech, Aylesbury, UK).

$\mathbf{C a}^{2+}$ Mobilization. Calcium assays were carried out on either Flp-In T-REx 293 cell lines, generated to inducibly express hFFA4 upon treatment with doxycycline, or $1321 \mathrm{~N} 1$ cells stably expressing the hFFA1 receptor. One day prior to the experiment, cells were seeded at 50,000 cells/well (Flp-In REx 293) or 25,000 cells/well (1321N1) in poly-D-lysine-coated, black, clear-bottom, 96-well microplates. Cells were allowed to adhere for 3-4 hours before the addition of $100 \mathrm{ng} / \mathrm{ml}$ doxycycline to induce receptor expression in the case of Flp-In T-REx 293 cell lines. The following day, cells were incubated in culture medium containing the calcium-sensitive dye Fura2-AM $(3 \mu \mathrm{M})$ for 45 minutes. Cells were then washed three times and then allowed to equilibrate for 15 minutes in HBSS prior to conducting the assay. Fura2 fluorescent emission was measured at $510 \mathrm{~nm}$ following excitation at both 340 and $380 \mathrm{~nm}$ during the course of the experiment using a Flexstation plate reader (Molecular Devices, Brambleside, UK). Calcium responses were then measured as the difference between $340 / 380$ ratios before and after the addition of the relevant compounds. For antagonism, the cells were preincubated for 15 minutes prior to agonist addition with HBSS supplemented with vehicle [1\% (v/v) DMSO], AH-7614, or TUG-1387 (10 $\mu \mathrm{M})$ prior to the addition of $50 \mu \mathrm{M} \alpha$ linolenic acid (aLA), $500 \mathrm{nM}$ TUG-891, or 13 nM TUG-770.

High-Content Imaging Quantitative Internalization Assay. hFFA4-mVenus Flp-In T-REx 293 cells were plated 75,000 cells/well in black with clear-bottom 96 -well plates. Cells were allowed to adhere for 3-6 hours before the addition of doxycycline $(100 \mathrm{ng} / \mathrm{ml})$ to induce receptor expression. After an overnight incubation, culture medium was replaced with serum-free DMEM containing the ligand to be assessed and incubated at $37^{\circ} \mathrm{C}$ for 30 minutes before fixation with $4 \%$ paraformaldehyde. After washing with phosphate-buffered saline, cell nuclei were stained for 30 minutes with Hoechst33342.

Plates were subsequently imaged using a Cellomics ArrayScan II high-content plate imager (Thermo Fisher Scientific, Paisley, UK). Images were processed to identify internalized mVenus, which was then normalized to cell number based on nuclei identified by Hoechst33342 staining, to obtain a quantitative measure of hFFA4mVenus internalization.

HTRF-Based Inositol Monophosphate Assay. Inositol monophosphate assays (Cisbio Bioassays, Codolet, France) were performed according to the manufacturer's instructions. In brief, a suspension of 7500 cells/well was incubated with the stated concentrations of agonist for 1 hour in the presence of $10 \mathrm{mM}$ lithium chloride ( $\mathrm{LiCl})$. Inositol monophosphate accumulation was subsequently measured using a Pherastar FS plate reader.

RNA Isolation and Reverse-Transcription Quantitative Polymerase Chain Reaction (RT-qPCR). Total RNA was isolated from C3H10T1/2 cells using an RNEasy mini kit (Qiagen, Manchester, UK). Following RNA isolation, reverse-transcription polymerase chain reaction was performed using Superscript III (Life Technologies), and the resultant cDNA was used as a template for quantitative polymerase chain reaction analysis using an ABI Prism 7300 sequence detector (Applied Biosystems, Paisley, UK). Cycling conditions were as follows: $50^{\circ} \mathrm{C}$ for 2 minutes, $95^{\circ} \mathrm{C}$ for 10 minutes, followed by 40 cycles of $95^{\circ} \mathrm{C}$ for 15 seconds and $60^{\circ} \mathrm{C}$ for 1 minute. FFA4, PPAR $\gamma$, and Runx 2 expressions were then defined relative to cyclophilin using the $2^{-\Delta \Delta \mathrm{Ct}}$ method

Western Blotting. Analysis of receptor phosphorylation was performed on mFFA4-eYFP cells that were pretreated with either $10 \mu \mathrm{M}$ AH-7614 or TUG-1387 for 30 minutes, after which time they were treated with $10 \mu \mathrm{M}$ TUG-891 for 5 minutes. Cell lysates were prepared and size fractionated on 4-12\% SDS-PAGE gels and transferred to nitrocellulose membranes. Nitrocellulose membranes containing resolved receptor proteins were incubated in Tris-buffered saline LI-COR blocking buffer (LI-COR Biosciences, Cambridge, UK) and incubated subsequently with a phospho-specific antiserum produced in house that is able to recognize phosphorylated $\mathrm{Thr}^{347}$ and $\mathrm{Ser}^{350}$ residues of the receptor (Prihandoko et al., 2016). Membranes were air-dried and scanned using an LI-COR Odyssey CLx Imager.

Oil Red O Staining. Untreated or differentiated C3H10T1/2 cells were fixed in $10 \%(\mathrm{v} / \mathrm{v})$ formalin for 60 minutes at room temperature. The cells were washed in $60 \%(\mathrm{v} / \mathrm{v})$ isopropanol and then incubated for 10 minutes with isopropanol supplemented with $0.6 \%$ (w/v) Oil Red O. The Oil Red O solution (Sigma-Aldrich) was then removed, and cells were washed $\times 4$ with $\mathrm{dH}_{2} \mathrm{O}$ and then stored in phosphate-buffered saline at $4^{\circ} \mathrm{C}$ until visualization using an Invitrogen EVOS FL Auto Imaging System (Life Technologies). After removal of all liquid, the Oil Red O stain was dissolved in isopropanol and the absorbance measured at $405 \mathrm{~nm}$ using a Pherastar FS reader. 
Statistical Analysis. Data are presented as the mean \pm S.E.M. of a minimum of three independent experiments performed in triplicate, unless otherwise stated in the respective figure legends. Data analysis was carried out using GraphPad Prism software (package v5.02; GraphPad Software, La Jolla, CA), with concentration-response data fitted to three-parameter sigmoidal curves. For allosteric modulation experiments, data sets were globally fit to an operational model of allosterism described previously (Hudson et al., 2014). To fit these data, the $\tau$ value for all allosteric modulators was constrained to reflect the lack of detectable agonism seen within these compounds, which allowed for curve fits yielding estimates of $\log \alpha, \log \beta, \log \mathrm{K}_{\mathrm{A}}$, and $\log \mathrm{K}_{\mathrm{B}}$. Statistical analyses were carried out using one-way analysis of variance followed by Tukey's post-hoc test.

\section{Results}

We synthesized and assessed the functional activity of AH-7614 (Fig. 1), a xanthene derivative of a diarylsulfonamidebased FFA4 agonist. This compound was originally described as an antagonist of FFA4, able to block effects of both the polyunsaturated $\omega-6$ fatty acid linoleic acid and the synthetic FFA4 agonist GSK137647A (Fig. 1) (Sparks et al., 2014), and has since been used in a number of functional studies (Quesada-López et al., 2016; Houthuijzen et al., 2017; Villegas-Comonfort et al., 2017) but without analysis of its mode of action. Indeed, AH-7614 inhibited, in a potent and concentration-dependent manner $\left(\mathrm{pIC}_{50}\right.$ vs. $\mathrm{EC}_{80}$ concentrations of the agonists), the ability of either the $\omega$-3 fatty acid aLA ( $\mathrm{pIC}_{50} 7.51 \pm 0.08, n=3$ ) or a synthetic orthobiphenyl-based agonist of FFA4, TUG-891 (Fig. 1) $\left(\mathrm{pIC}_{50} 8.13 \pm 0.08, n=3\right.$ ) (Shimpukade et al., 2012; Hudson et al., 2013; Butcher et al., 2014), to promote $\mathrm{Ca}^{2+}$ mobilization in Flp-In T-REx 293 cells induced to express hFFA4-eYFP (Fig. 2, A and B). Similar results were obtained when measuring the ability of AH-7614 to inhibit agonist-induced interactions of hFFA4 with $\beta$-arrestin-2 following coexpression of these two proteins in HEK293T cells (Fig. 2, C and D). Importantly for subsequent studies, AH-7614 also functionally antagonized effects of both aLA and TUG-891 at the corresponding mouse ortholog of the receptor (mFFA4) (Fig. 2, E and F). AH-7614 showed selectivity for FFA4, as it was unable to antagonize activation of the other long-chain fatty acid receptor, FFA1 (Milligan et al., 2015, 2017), in studies in which the synthetic alkyne-based FFA1 agonist TUG-770 (Christiansen et al., 2013) promoted elevation of intracellular $\mathrm{Ca}^{2+}$ in $1321 \mathrm{~N} 1$ cells stably transfected to express a human FFA1 construct (Fig. 2G).

In similar $\mathrm{EC}_{80}$ inhibition experiments, $\mathrm{AH}-7614$ was also effective in blocking TUG-891-mediated internalization of FFA4 from the cell surface (Fig. $3 \mathrm{~A})\left(\mathrm{pIC}_{50}=7.70 \pm 0.10, n=3\right)$. We therefore used this internalization assay, with an endpoint

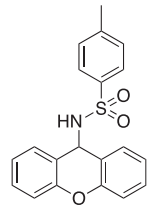

AH-7614
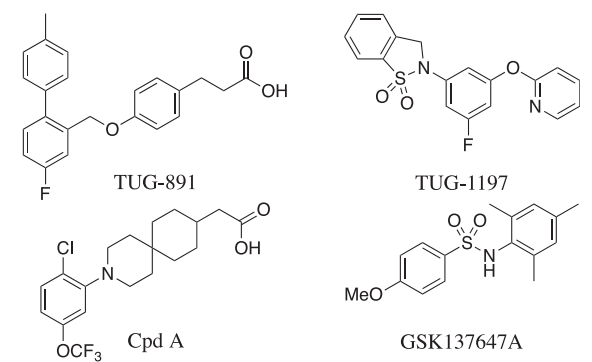

Fig. 1. The chemical structures of the FFA4 antagonist AH-7614 and a range of FFA4 agonists (TUG-891, Cpd A, GSK137647A, and TUG-1197).
30 minutes after addition of agonist to facilitate achievement of ligand equilibrium, to probe the mechanism of AH-7614mediated blockade of FFA4. Receptor internalization experiments were conducted in which the ability of defined concentrations of preadded AH-7614 to block internalization in response to various concentrations of TUG-891 was assessed (Fig. 3B). In these experiments, it was clear that the primary inhibitory effect of AH-7614 was to produce a decrease in the maximal response to
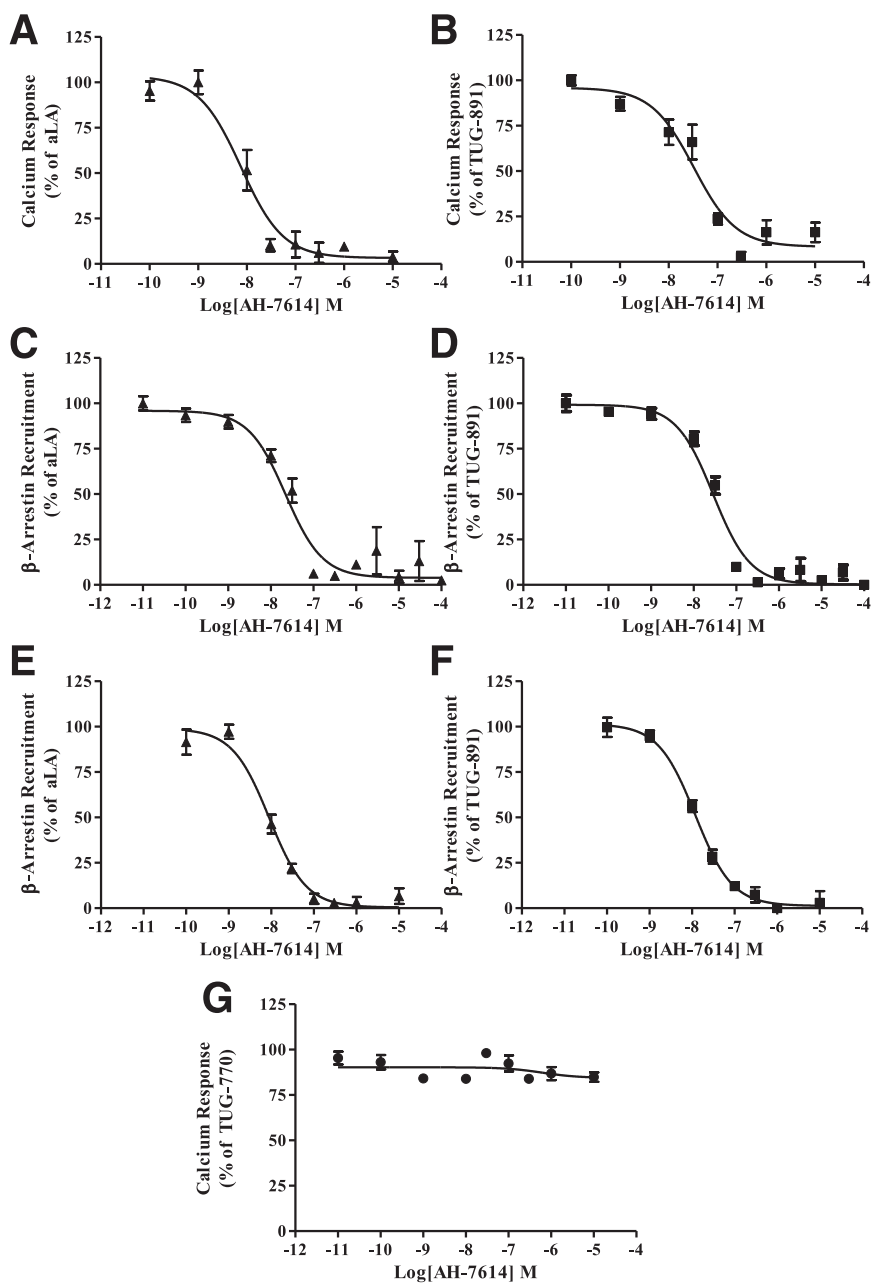

Fig. 2. AH-7614 is a potent and selective inhibitor of both human and murine FFA4 function. Flp-In T-REx 293 cells induced to express hFFA4eYFP were pretreated with either vehicle $[1 \%(\mathrm{v} / \mathrm{v}) \mathrm{DMSO}]$ or increasing concentrations of AH-7614 for 15 minutes, after which time they were treated with either $50 \mu \mathrm{M}$ aLA (A) or $500 \mathrm{nM}$ TUG-891 (B). Both aLA and TUG-891 induced calcium release that was potently inhibited in the presence of AH-7614 (aLA, pIC $50=7.51 \pm 0.08, n=3$; TUG-891, pIC $_{50}=$ $8.13 \pm 0.08, n=3$ ). HEK293T cells transiently expressing hFFA4-eYFP and $\beta$-arrestin-2-Renilla luciferase were preincubated with either vehicle $[1 \%(\mathrm{v} / \mathrm{v})$ DMSO] or increasing concentrations of AH-7614. The cells were then treated with either $50 \mu \mathrm{M}$ aLA (C) or $500 \mathrm{nM}$ TUG-891 (D), and $\beta$-arrestin-2 recruitment was subsequently determined using a BRETbased assay. Both aLA and TUG-891 promoted $\beta$-arrestin- 2 recruitment that was potently inhibited ( $\mathrm{aLA}, \mathrm{pIC}_{50}=7.66 \pm 0.05, n=5$; TUG-891, $\mathrm{pIC}_{50}=7.55 \pm 0.07, n=5$ ) in the presence of increasing concentrations of AH-7614. mFFA4-dependent $\beta$-arrestin-2 recruitment in the presence of either $50 \mu \mathrm{M}$ aLA (E) or $500 \mathrm{nM}$ TUG-891 (F) was also potently inhibited $\left(\mathrm{aLA}, \mathrm{pIC} \mathrm{IC}_{50}=8.05 \pm 0.08 n=3\right.$; TUG-891, $\mathrm{pIC}_{50}=7.93 \pm 0.06, n=3$ ) by AH-7614. However, AH-7614 had no effect on TUG-770-induced calcium release in $1321 \mathrm{~N} 1$ cells stably transfected with hFFA1 receptor (G), indicating that AH-7614 is not an antagonist at this receptor. Data represent experiments performed in triplicate three times or more. 


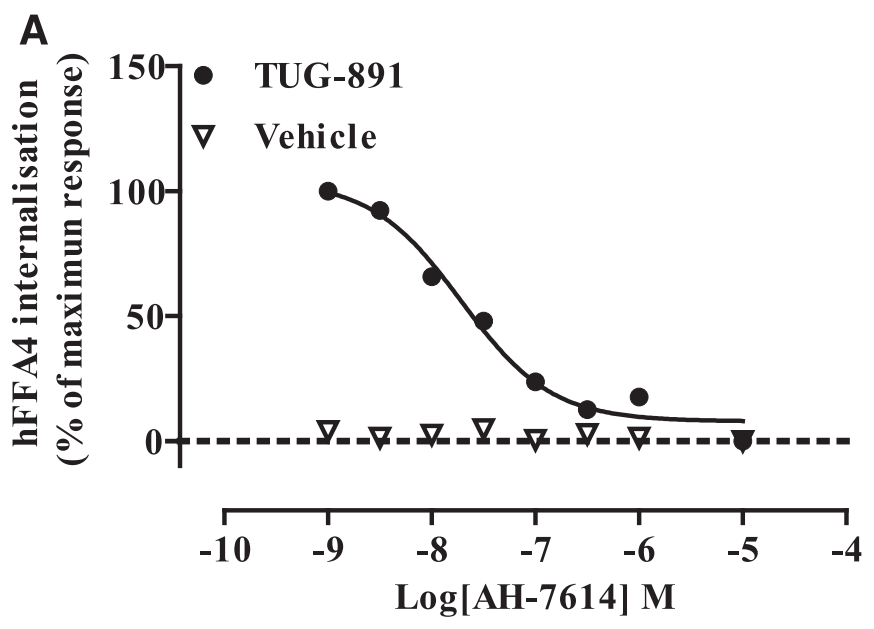

B

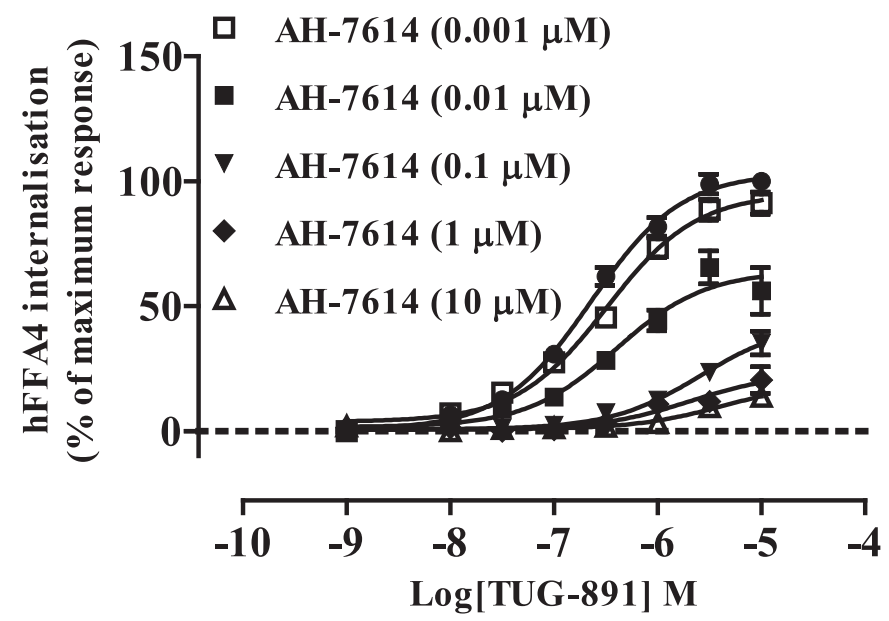

Fig. 3. AH-7614 blocks agonist-induced receptor internalization of the human FFA4 receptor. Flp-In T-REx 293 cells induced to express hFFA4mVenus were pretreated with $10 \mu \mathrm{M}$ AH-7614 for 15 minutes, after which time cells were further treated with either vehicle $[0.1 \%(\mathrm{v} / \mathrm{v}) \mathrm{DMSO}]$ or TUG-891 $(3 \mu \mathrm{M})$ for 30 minutes (A) and subsequently fixed. AH-7614 prevented TUG-891 induced receptor internalization $\left(\mathrm{pIC}_{50}=7.70 \pm 0.10\right)$. Cells were pretreated with varying concentrations of $\mathrm{AH}-7614$ and exposed to increasing concentrations of TUG-891 (B) for 30 minutes, after which they were fixed. Cells were imaged using a Cellomics ArrayScan II, and the extent of internalization of the receptor construct was quantified.

TUG-891. Although this is consistent with outcomes reported by Sparks et al. (2014) using intracellular $\mathrm{Ca}^{2+}$ assays, the longer time course of the internalization studies largely eliminates potential issues of ligand hemiequilibrium that can greatly influence outcomes and mechanistic interpretation in assays, such as those based on $\mathrm{Ca}^{2+}$ mobilization, that use much shorter endpoints (Charlton and Vauquelin, 2010). These findings indicated that $\mathrm{AH}-7614$ is not a competitive antagonist of FFA4. Interestingly, even at the highest concentration of AH-7614 tested, a residual response to TUG- 891 remained. This response to TUG-891 was similar in the presence of 1 and $10 \mu \mathrm{M} \mathrm{AH-7614,}$ and as such, the effect of AH-7614 appeared to saturate. Such an outcome is consistent with AH-7614 functioning as an NAM of FFA4.

As it is common for small chemical changes in allosteric GPCR ligands to significantly alter the details of their allosteric behavior (Wood et al., 2011; Hudson et al., 2014), we next synthesized derivatives of AH-7614 and assessed their activity at FFA4. Two key derivatives were considered. In the first, the sulfonamide of AH-7614 was replaced with an amide (TUG-1387), whereas in the second, the xanthine was replaced with a thioxanthene (TUG-1506) (Fig. 4A). These analogs were tested for their ability to antagonize $\mathrm{EC}_{80}$ concentrations of TUG-891 (Fig. 4B) in a $\beta$-arrestin-2 recruitment assay. The thioxanthene-containing TUG-1506 retained the ability to inhibit TUG-891 $\left(\mathrm{pIC}_{50}=6.38 \pm 0.09, n=3\right.$ ) but with lower potency than the xanthene containing $\mathrm{AH}-7614$. In contrast, the amide-containing TUG-1387 lacked all ability to inhibit TUG-891-mediated activation of FFA4.

As AH-7614, and likely TUG-1506, appeared to be NAMs of FFA4 function, we characterized and quantified the nature and extent of their NAM properties against synthetic FFA4 agonists from several distinct chemotypes. A common feature of GPCR allosteric modulators is that they may show "probe dependence," producing different allosteric effects depending on the orthosteric agonist being modulated (May et al., 2007). Therefore, we conducted experiments in which AH-7614 (Fig. 5, A-D) and TUG-1506 (Fig. 5, E-H) were used to antagonize $\beta$-arrestin- 2 recruitment to FFA4 induced by synthetic agonists from each of four distinct chemotypes: TUG-891 (Shimpukade et al., 2012), TUG-1197 (Azevedo et al., 2016), GSK137647A (Sparks et al., 2014), and Cpd A (Oh et al., 2014) (Fig. 1). Data from these experiments were then fit to an operational model of allosterism to quantify the allosteric effect each NAM had on affinity of each orthosteric agonist $(\alpha)$, the allosteric effect on efficacy of each orthosteric agonist $(\beta)$, the affinity of the orthosteric agonists $\left(\mathrm{K}_{\mathrm{A}}\right)$, and the affinity of the modulator $\left(\mathrm{K}_{\mathrm{B}}\right)$ (Table 1). AH-7614 reduced the maximal response to each agonist tested, and produced a modest reduction in agonist potency (Fig. 5, A-D). This corresponded to $\log \alpha$ (Fig. 5I; Table 1) and $\log \beta$ (Fig. 5J; Table 1) values that were both less than zero for each of the four agonists. However, although the $\log \alpha$ values were broadly similar for each agonist, the $\log \beta$ for GSK137647A was significantly lower $(P<0.01)$ than the value obtained for either TUG-891 or Cpd A, suggesting a subtle level of probe dependence in AH-7614 modulation of FFA4 activity. This can be noted in the concentration-response curves by the observation that, although high concentrations of AH-7614 eliminated measureable response to GSK137647A (Fig. 5C), a residual response was apparent for all other agonists, even at $30 \mu \mathrm{M}$ AH-7614 (Fig. 5, A, B, and D). Importantly, the agonist responses were similar in the presence of between 3 and $30 \mu \mathrm{M} \mathrm{AH}-7614$, indicating that the inhibitory properties of AH-7614 were saturable, a hallmark of allosteric modulators.

In examining the allosterism between TUG-1506 and the various FFA4 agonists (Fig. 5, E-H), much more striking probe dependence was apparent. Most notably, whereas TUG1506 primarily shifted the potency of TUG-891 (Fig. 5E) and Cpd A (Fig. 5H) with little effect on maximal response, the opposite was true for TUG-1197 and GSK137647A, where TUG-1506 depressed the maximal response without affecting agonist potency. This was reflected in the operational model curve fit parameters for these experiments, where a large negative $\log \alpha$ was observed for TUG-891 and Cpd A (Fig. 5K; Table 1) but a large negative $\log \beta$ was observed for TUG-1197 and GSK137647A (Fig. 5L; Table 1). This is a clear indication of the probe dependence in the NAM properties of TUG-1506. Interestingly, this may be related to the chemical nature of the 
A<smiles>Cc1ccc(S(=O)(=O)NC2c3ccccc3Oc3ccccc32)cc1</smiles>

AH-7614<smiles>Cc1ccc(S(=O)(=O)NC2c3ccccc3Sc3ccccc32)cc1</smiles>

TUG-1506<smiles>Cc1ccc(C(=O)NC2c3ccccc3Oc3ccccc32)cc1</smiles>

TUG-1387
B

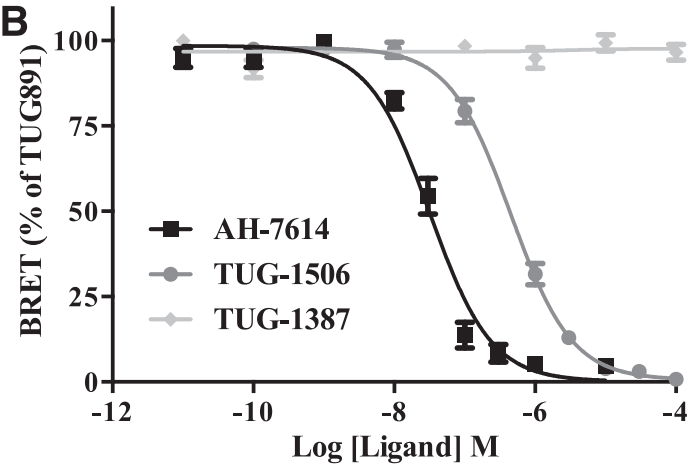

Fig. 4. TUG-1387 and TUG-1506 are chemical derivatives of AH-7614 with varying activity at FFA4. (A) Chemical structures of AH-7614, TUG-1387, and TUG-1506. HEK293T cells transiently coexpressing hFFA4-eYFP and $\beta$-arrestin-2-Renilla luciferase were preincubated with vehicle $(0.1 \%$ DMSO) or increasing concentrations of AH-7614, TUG-1387, or TUG-1506. $\beta$-Arrestin-2 recruitment to the receptor was then determined in the presence $500 \mathrm{nM}$ TUG-891 (B). All data represent experiments carried out in triplicate at least three times.

agonists, with TUG-891 and Cpd A both being carboxylatebased FFA4 agonists, whereas TUG-1197 and GSK137647A are each sulfonamide-based agonists. Importantly, once again, the inhibitory effects of TUG-1506 were saturable in all cases, entirely consistent with defining this compound as an NAM at FFA4. Similar experiments were also conducted with TUG-1387 against each FFA4 agonist, although in this case, given that TUG-1387 had already been shown to lack activity at FFA4, only a single high concentration of TUG1387 was used (Fig. 6, A-D). TUG-1387 did not produce an
NAM effect on TUG-891, TUG-1197, or Cpd A, and only produced a very modest effect on GSK137647A. Overall, these results are consistent with either TUG-1387 having no affinity for FFA4 or it being a silent allosteric modulator that, even if it does bind the receptor, does not affect orthosteric agonist function.

To further assess the potential for using AH-7614 in combination with TUG-1387 to define biologic functions of FFA4, we aimed to confirm the broader ability of AH-7614, but not TUG-1387, to block additional FFA4 signaling pathways. We
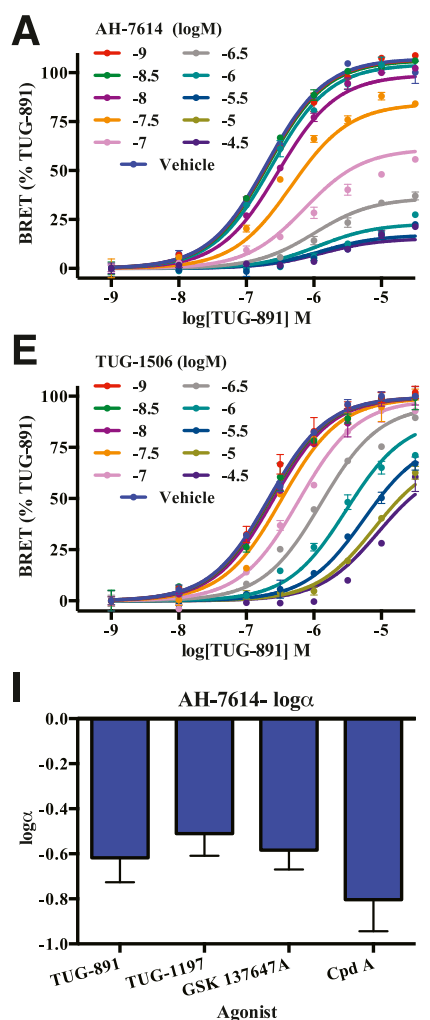

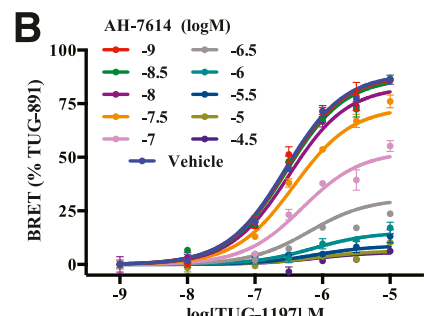

$\mathbf{F}$
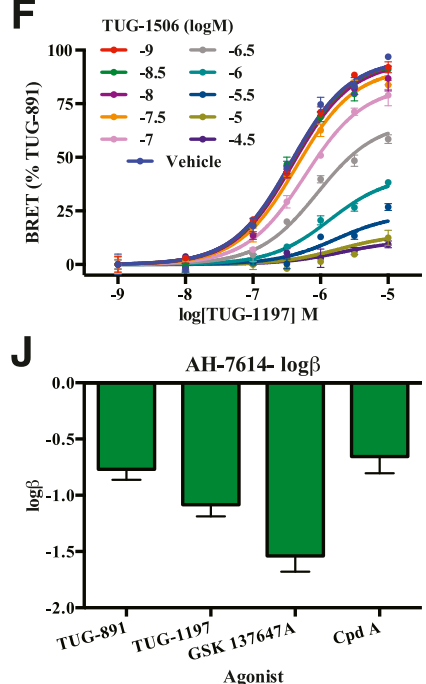
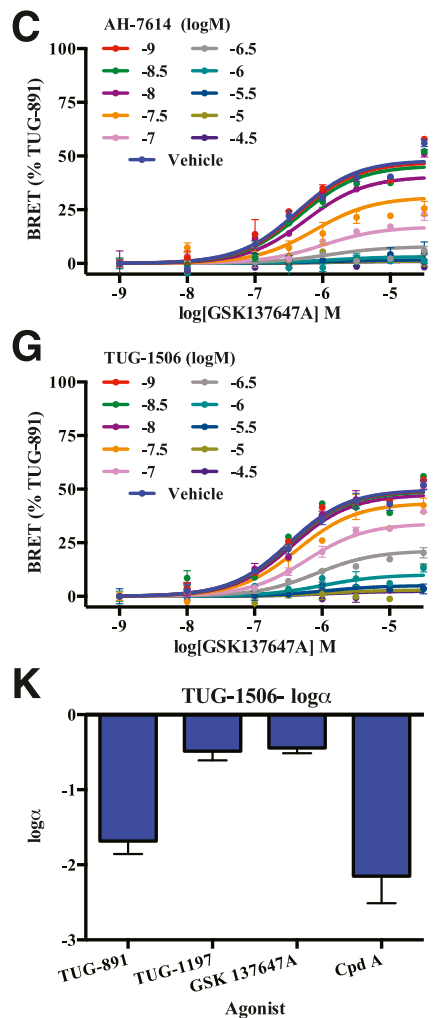

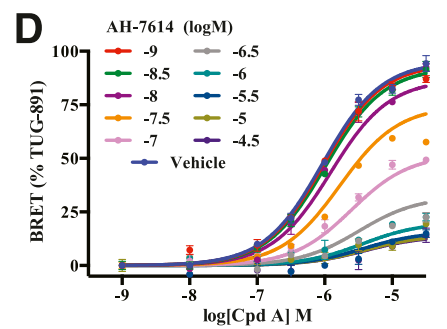

H
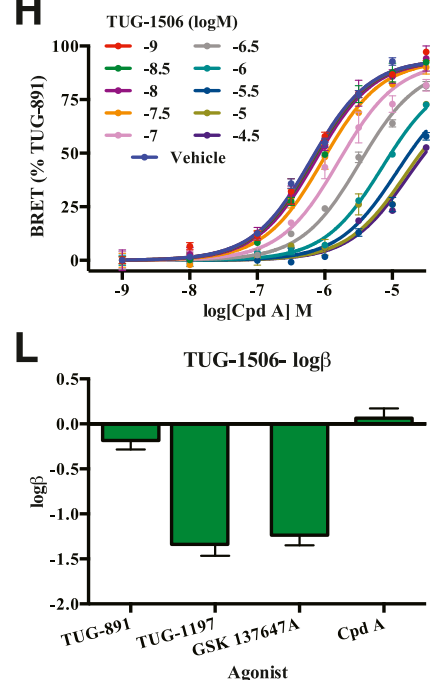

Fig. 5. AH-7614 and TUG-1506 are probe-dependent negative allosteric modulators of FFA4. The nature of AH-7614 (A-D) and TUG-1506 (E-H) allosteric modulation of FFA4 function was probed by their ability to limit recruitment of $\beta$-arrestin- 2 to hFFA4-eYFP induced by varying concentrations of four chemically distinct FFA4 agonists [TUG-891 (A and E), TUG-1197 (B and F), GSK137647A (C and G), and Merck compound A (Cpd A) (D and H)] using HEK293T cells transiently coexpressing hFFA4-eYFP and $\beta$-arrestin-2-Renilla luciferase. Data are fitted to an operational model of allosterism (Hudson et al., 2014). Estimated parameters for $\log \alpha$ and $\log \beta$ are shown for both AH-7614 (I and J) and TUG-1506 (K and L) when assessed at each of the four agonists. Data shown are from representative experiments (N numbers for each agonist-NAM combination are reported in Table 1) fit to an operational model of allosterism (Hudson et al., 2014). 
TABLE 1

Operational model curve-fit parameters for AH-7614 and TUG-1506

\begin{tabular}{lccccc}
\hline \multicolumn{1}{c}{ Agonist } & $\log \alpha$ & $\log \beta$ & $\mathrm{pK}_{\mathrm{A}}$ & $\mathrm{pK}_{\mathrm{B}}$ & $N$ \\
\hline AH-7614 & & & & & \\
TUG-891 & $-0.80 \pm 0.11$ & $-0.77 \pm 0.09$ & $6.77 \pm 0.14$ & $7.98 \pm 0.24$ & 4 \\
TUG-1197 & $-0.52 \pm 0.09$ & $-1.08 \pm 0.10$ & $6.44 \pm 0.05$ & $7.82 \pm 0.26$ & 5 \\
GSK137647A & $-0.58 \pm 0.09$ & $-1.54 \pm 0.14$ & $6.32 \pm 0.04$ & $8.14 \pm 0.21$ & 3 \\
Cpd A & $-0.80 \pm 0.14$ & $-0.66 \pm 0.15$ & $6.31 \pm 0.22$ & $8.17 \pm 0.26$ & 3 \\
TUG-1506 & & & & \\
TUG-891 & $-1.68 \pm 0.17$ & $-0.18 \pm 0.10$ & $6.79 \pm 0.11$ & $7.46 \pm 0.06$ & 4 \\
TUG-1197 & $-0.48 \pm 0.12$ & $-1.34 \pm 0.13$ & $6.48 \pm 0.08$ & $6.90 \pm 0.04$ & 3 \\
GSK137647A & $-0.44 \pm 0.07$ & $-1.24 \pm 0.11$ & $6.44 \pm 0.03$ & $7.04 \pm 0.10$ & 3 \\
Cpd A & $-2.15 \pm 0.36$ & $0.06 \pm 0.11$ & $6.46 \pm 0.18$ & $7.28 \pm 0.02$ & 3 \\
\hline
\end{tabular}

explored both FFA4-mediated accumulation of inositol monophosphates (Fig. 7A) and agonist-induced phosphorylation of $\mathrm{Thr}^{347}$ and $\mathrm{Ser}^{350}$ residues within the C terminus of FFA4 detected with previously described phospho-FFA4 antisera (Butcher et al., 2014; Prihandoko et al., 2016) (Fig. 7B). In each case, the agonist response was functionally inhibited by AH-7614, but was not affected by TUG-1387. Importantly for studies on more physiologically relevant systems, we also found that TUG-1387 lacked activity at the related fatty acid receptor FFA1 in experiments measuring calcium release in 1321N1-hFFA1 cells (not shown).
Recently, it has been suggested that FFA4 is able to act as a bipotential regulator of osteogenic and adipogenic differentiation of bone marrow-derived mesenchymal stem cells (Gao et al., 2015). Furthermore, FFA4 has been proposed to be a key player in the activation of brown adipose tissue (QuesadaLopez et al., 2016), further reinforcing a role for FFA4 in adipose tissue physiology. To further assess the role of FFA4 in adipogenic differentiation, and to demonstrate the utility of the FFA4 NAM (AH-7614) when used in combination with TUG-1387 to interrogate FFA4 biology, we used the murine mesenchymal stem cell line C3H10T1/2 (Tang et al., 2004;
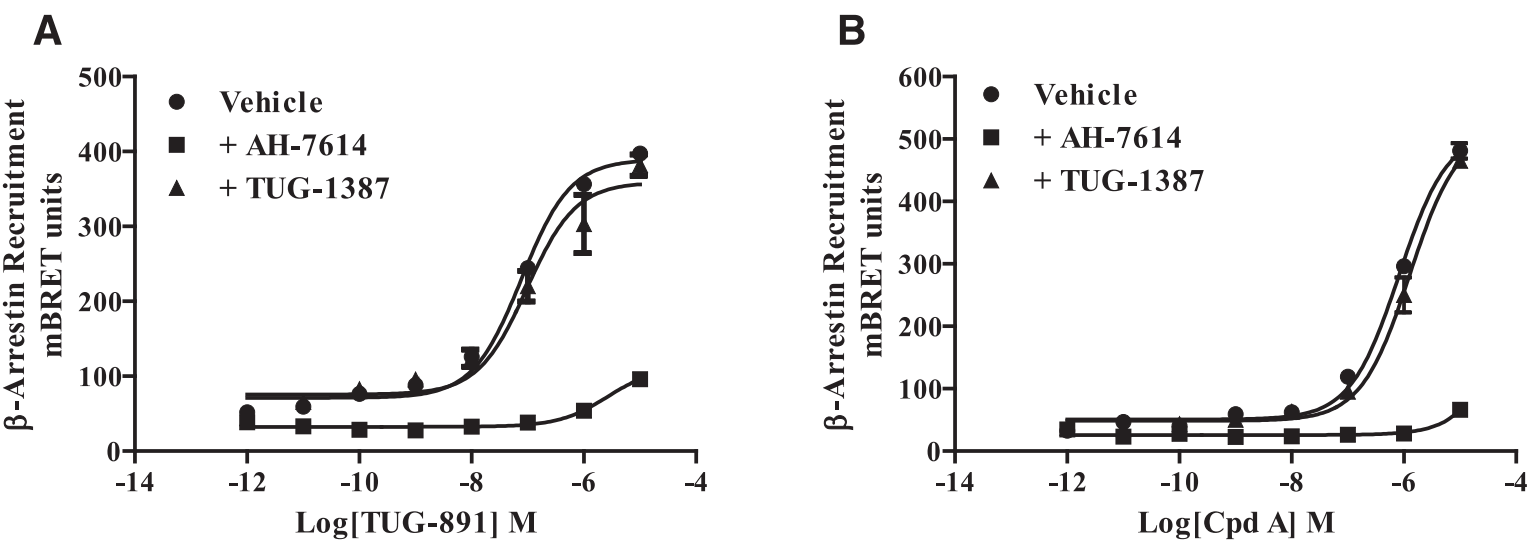

C
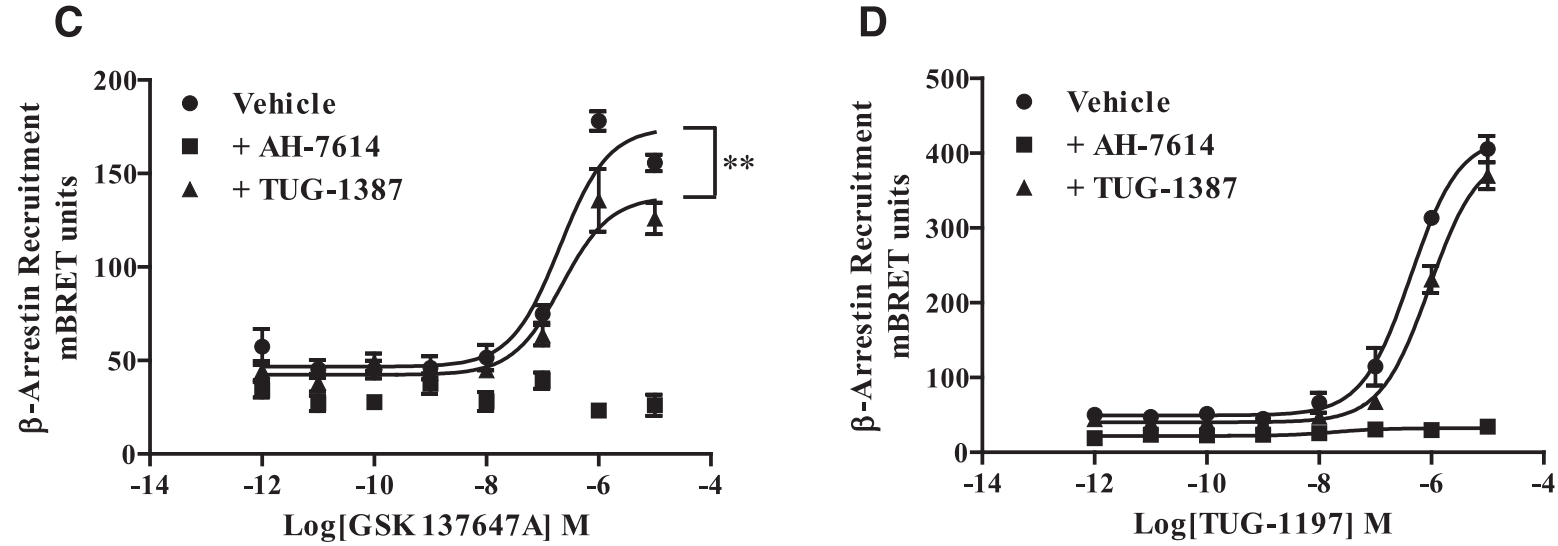

Fig. 6. TUG-1387 does not antagonize the effects of distinct FFA4 agonist chemotypes. HEK293T cells transiently expressing mFFA4-eYFP and $\beta$-arrestin-2-Renilla luciferase constructs were pretreated for 30 minutes with vehicle, $10 \mu \mathrm{M}$ AH-7614, or $10 \mu \mathrm{M}$ TUG-1387. They were then treated with TUG-891 (A), Cpd A (B), GSK137647A (C), or TUG-1197 (D) to assess receptor-mediated arrestin recruitment. AH-7614 was able to block $\beta$-arrestin2 recruitment in all cases, whereas TUG-1387 did not have any effect except to produce a small but significant $(* * P<0.001)$ reduction of the efficacy of GSK137647A (C). Data represent experiments performed in triplicate three/four times. mBRET, units are equal to the 535/475 nm emission ratio multiplied by 1000 . 
A

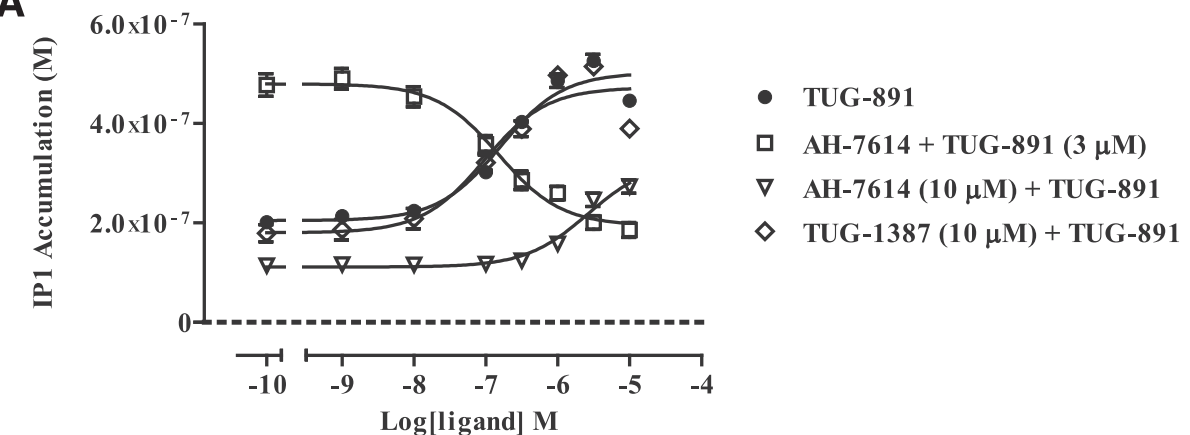

B
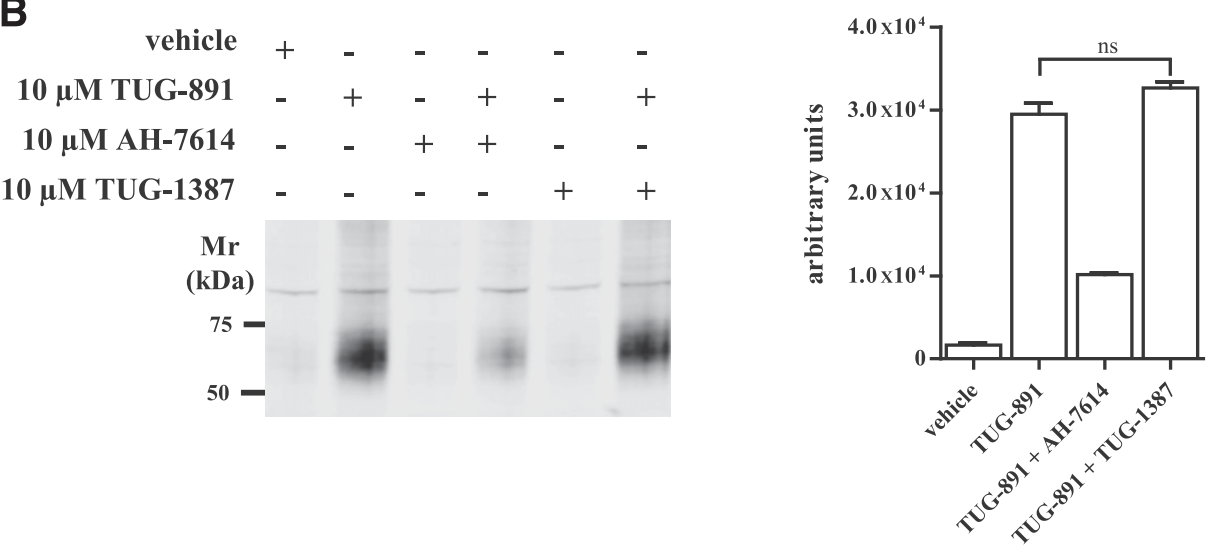

Fig. 7. AH-7614, but not TUG-1387, blocks agonist-induced elevation of intracellular inositol monophosphates and phosphorylation of FFA4. (A) FFA4-mediated inositol monophosphate (IP1) production was measured in cells expressing hFFA4-mVenus. TUG-891 (closed circles) promoted accumulation of IP1. Pretreatment with either $10 \mu \mathrm{M}$ AH-7614 (inverted triangles) or increasing concentrations of this molecule (open squares) blocked IP1 accumulation. By contrast, pretreatment with TUG-1387 was without effect (open diamonds). (B) mFFA4eYFP cells were pretreated with vehicle or various concentrations of AH-7614 or TUG1387 for 30 minutes followed by treatment with $10 \mu \mathrm{M}$ TUG-891 for 5 minutes. Cell lysates were prepared and resolved by SDSPAGE and immunoblotted with an mFFA4specific phospho-antiserum that recognizes phosphorylation of residues $\mathrm{Thr}^{347}$ and $\mathrm{Ser}^{350}$ (Prihandoko et al., 2016). Quantification of a series of such immunoblots is shown in the right-hand panel. ns, $P>0.05$.

Hashimoto et al., 2016; Lee et al., 2016). Here, differentiation toward an adipocyte phenotype was produced by maintaining the cells in the presence of an induction mixture (IID) consisting of $100 \mathrm{nM}$ insulin, $500 \mu \mathrm{M}$ IBMX, and $10 \mathrm{nM}$ dexamethasone for 5 days. Oil Red $\mathrm{O}$ staining effectively visualized the development of triglyceride deposits associated with adipogenesis (Fig. 8A). In concert, exposure to the IIDcontaining medium produced clear upregulation of mRNA for the adipogenic development marker, PPAR $\gamma$ (Fig. 8B). This effect was not produced simply by cell confluence on the tissue culture plate (Fig. 8B). In parallel, levels of Runt-related transcription factor 2 (Runx2) mRNA, a key transcription factor associated with osteoblast differentiation (Xu et al., 2015; Yuan et al., 2016), were greatly reduced (Fig. 8C). Over this time, frame levels of mFFA4 mRNA were also markedly increased by cell maintenance in the IID medium; interestingly, however, an equivalent upregulation of mFFA4 mRNA was also produced simply by maintaining C3H10T1/2 cells at confluence for a 5-day period (Fig. 8D). The ability of C3H10T1/2 cells to differentiate toward the adipocyte phenotype was clearly dependent upon signaling from FFA4, because treatment of cells with AH-7614 along with the IID medium greatly reduced visual observation of triglyceride stores as detected by Oil Red $\mathrm{O}$ staining and its quantification (Fig. 9, A and B). Treatment with AH-7614 also limited IIDinduced PPAR $\gamma$ mRNA induction (Fig. 9C), without affecting the associated downregulation of Runx2 expression (Fig. 9D). In contrast, treatment of C3H10T1/2 cells with TUG-1387 during the induction period with the IID-containing medium had no significant effect on the development of Oil Red O staining (Fig. 9, A and B). Taken together, these data indicate that TUG-1387, although structurally related, lacks activity at both FFA4 and the related FFA1, and therefore indicate this compound will be a useful chemical control to confirm that biologic effects produced by AH-7614 and related compounds, such as TUG-1506, are in fact FFA4-mediated.

\section{Discussion}

The availability of pharmacological tool compounds is central to efforts to define functions of many cellular proteins, including GPCRs, and to assess such proteins as potential therapeutic targets. However, for poorly and recently characterized receptors, such tool compounds are often lacking; described largely in the chemical/patent literature and, therefore, often of limited availability; and/or are poorly characterized in terms of selectivity and potential off-target effects. Within the group of GPCRs that respond to nonesterified, or "free," fatty acids, the most broad-reaching pharmacopoeia to date targets the long-chain fatty acid receptor FFA1 (Milligan et al., 2017). This reflects that FFA1 has been targeted therapeutically and in human clinical trials to assess whether activation of this receptor might provide an approach to treat type II diabetes (Watterson et al., 2014; Li et al., 2016; Mohammad, 2016; Ghislain and Poitout, 2017). Although the second GPCR that is activated by longer-chain free fatty acids, FFA4, is also frequently suggested as a potential therapeutic target for diabetes and other metabolic disorders (Li et al., 2016; Moniri, 2016; Hansen and Ulven, 2017), this lags behind studies on FFA1, and no synthetic ligands with activity at this receptor have yet entered clinical studies (Milligan et al., 2017). As a result, even tool compounds that are useful for assessing roles of this receptor are less widely available or understood (Hansen and Ulven, 2017). Moreover, as clear consensus is based on the therapeutic potential of agonism of FFA4 (Li et al., 2016; Moniri, 2016), little effort 
A
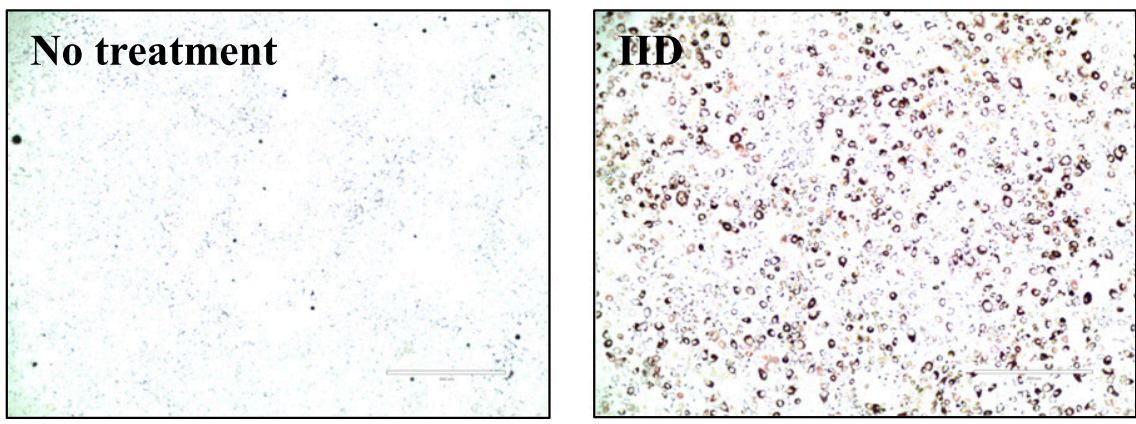

B
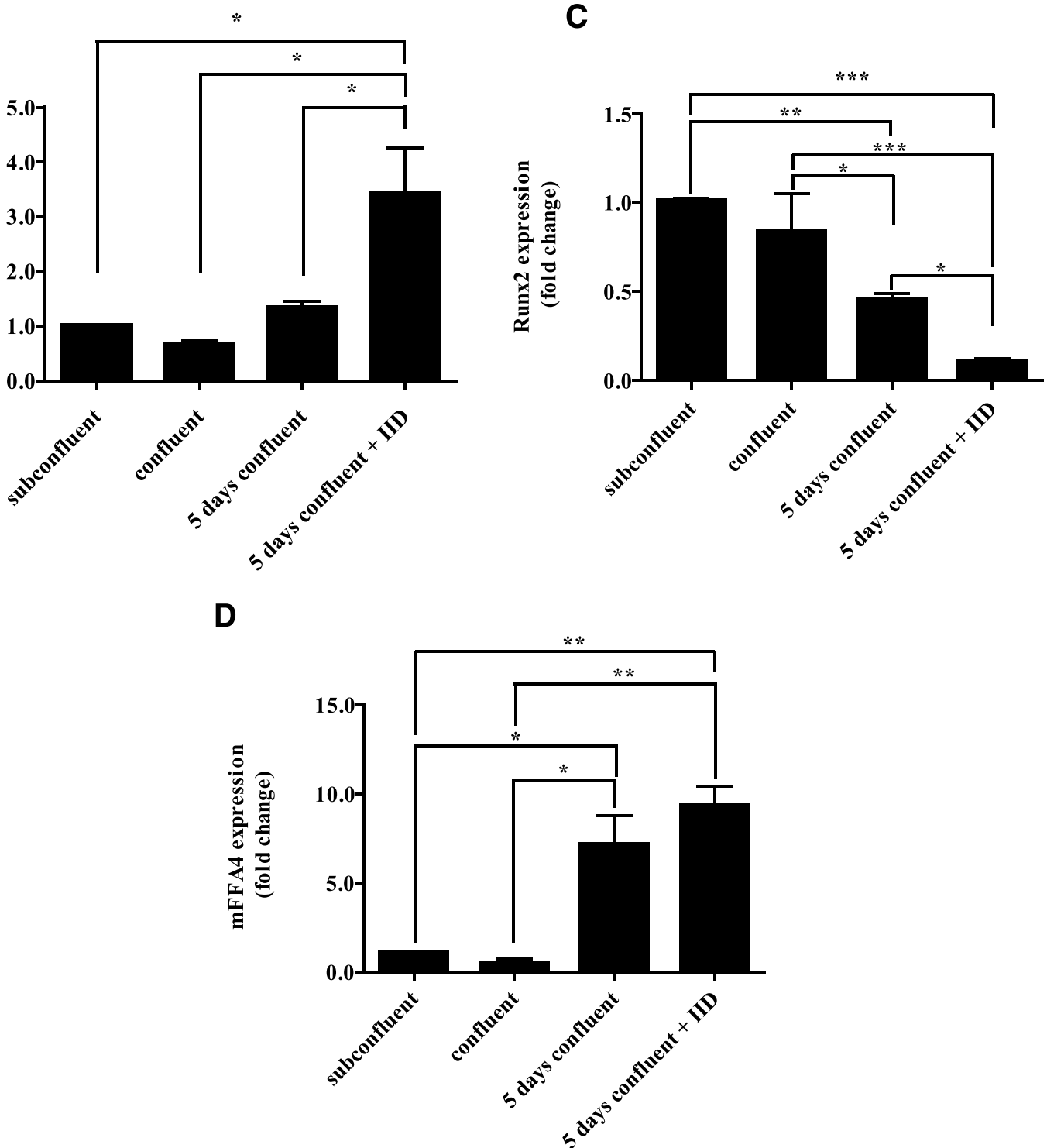

Fig. 8. mRNA levels of FFA4 and PPAR $\gamma$ are upregulated in C3H10T1/2 cells by differentiation toward the adipocyte phenotype. (A) C3H10T1/2 cells were differentiated toward an adipocyte phenotype by treatment with IID medium. Confirmation of effective differentiation after 5 days of treatment was obtained by staining for triglyceride droplets within the cells using Oil Red O. RT-qPCR was performed to assess changes in expression levels of PPAR $\gamma(\mathrm{B})$, Runx2 (C), and mFFA4 (D) under conditions of subconfluence, confluence, 5 days postconfluence, and 5 days postconfluence in the presence of IID. Data are presented as the group mean \pm S.E.M. of three independent experiments $\left(* \operatorname{different}\right.$ at $P<0.05,{ }^{* *} P<0.01$, and ${ }^{* * *} P<$ $0.001)$. Scale bar in $(A)=400 \mu \mathrm{m}$.

has been expended to identify, report, or characterize antagonists of this receptor, despite antagonist tool compounds being a traditional touchstone for detailed pharmacological analysis.
The only inhibitor of FFA4 function reported to date is AH-7614 (Sparks et al., 2014). Although Sparks et al. (2014) suggested that this compound would likely act as a competitive antagonist of FFA4, the limited data presented in their 
A
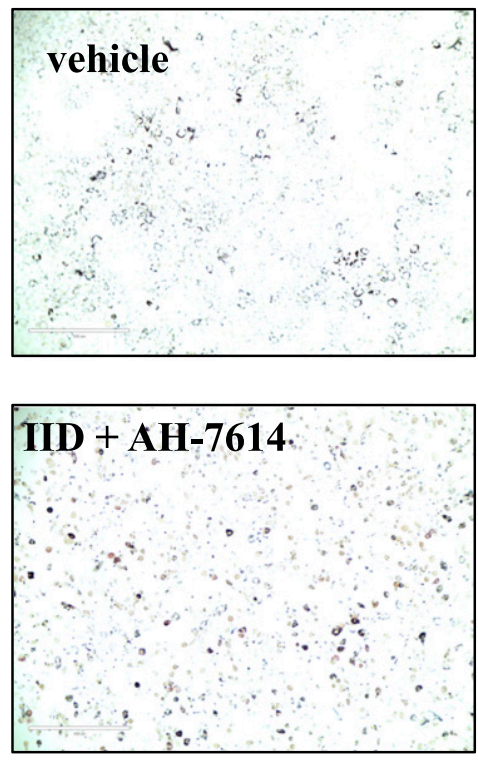
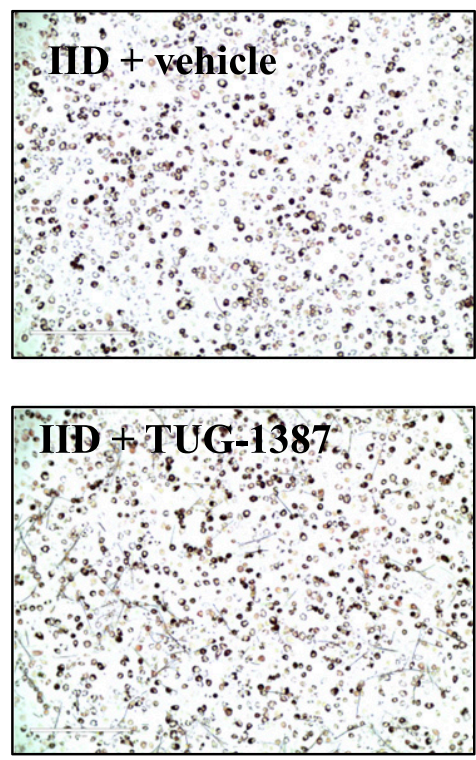

B

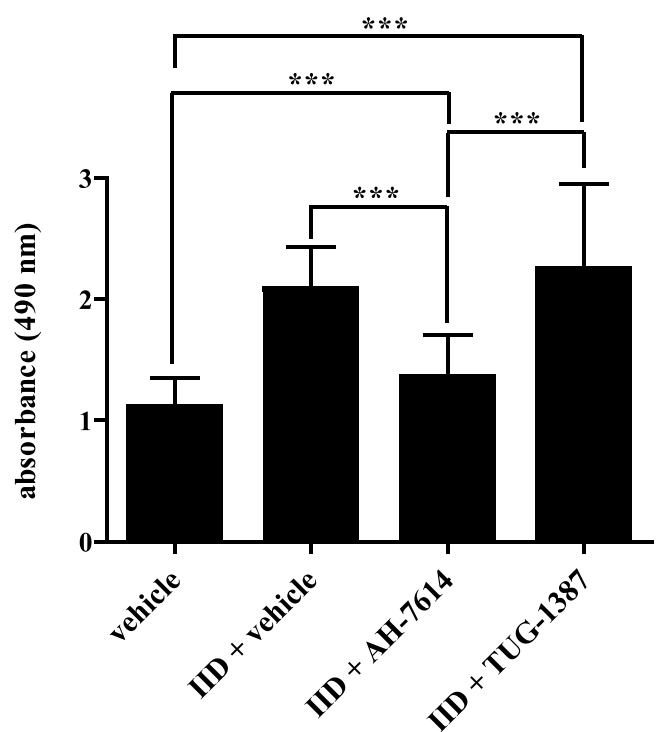

D

C
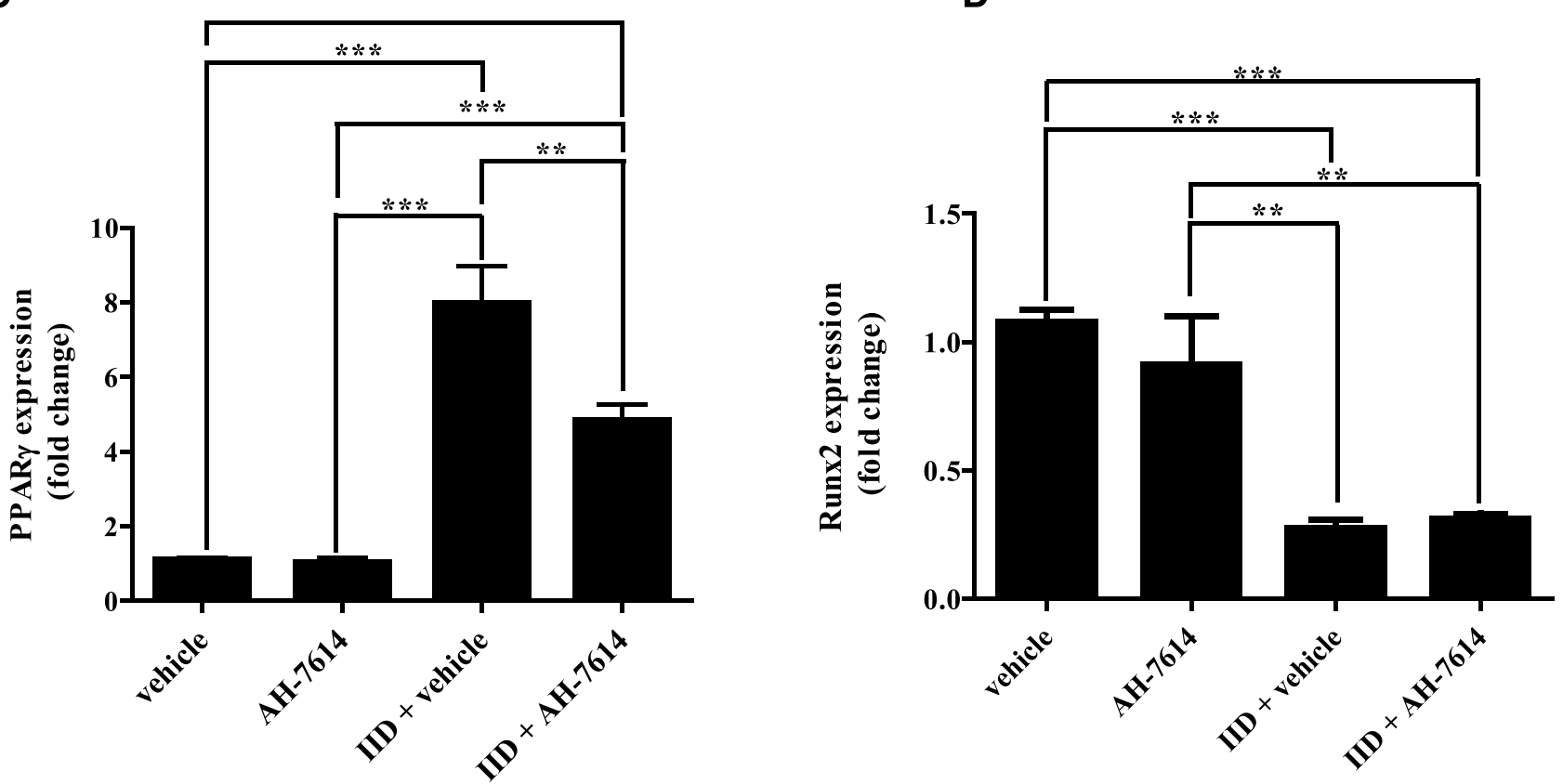

Fig. 9. Adipocyte differentiation of C3H10T1/2 cells requires FFA4 signaling. (A) C3H10T1/2 cells were differentiated (IID) in the presence of vehicle (0.1\% DMSO), $10 \mu \mathrm{M}$ AH-7614, or $10 \mu \mathrm{M}$ TUG-1387 compared with a nondifferentiated control and then stained with Oil Red O. (B) Oil Red O staining was subsequently dissolved in isopropanol and then quantified by measuring absorbance at $405 \mathrm{~nm}(n=10$, data presented as mean \pm S.E.M.). RT-qPCR analysis of PPAR $\gamma(n=5)(\mathrm{C})$ and Runx2 $(n=4)(\mathrm{D})$ levels was then performed on differentiated (IID) and nondifferentiated (vehicle) C3H10T1/2 cells in the presence or absence of $10 \mu \mathrm{M}$ AH-7614. Data are presented as the mean \pm S.E. $(* * P<0.01$, and $* * * P<0.001)$. Scale bar in $(\mathrm{A})=400 \mu \mathrm{m}$.

report did not actually suggest such a mode of action, which appeared to be noncompetitive, at least in assays measuring regulation of intracellular $\mathrm{Ca}^{2+}$ levels. The studies reported here expand on this, defining AH-7614 as an NAM of FFA4 function. This conclusion is supported by several hallmarks of allosterism (May et al., 2007), including that the ability of AH-7614 to inhibit FFA4 function is saturable, and that AH-7614 displays some level of probe dependence. More striking, however, in this regard is the chemical derivative of AH-7614, TUG-1506, described for the first time in these studies, which shows clear probe dependence depending on the chemical nature of the FFA4 agonist it is modulating. Specifically, this compound is an NAM primarily of ligand affinity for the two carboxylate-containing agonists tested, but primarily an NAM of efficacy for the noncarboxylate, sulphonamide-based agonists. Such changes in allosteric modulation are commonly observed with small chemical changes in allosteric ligands (Wood et al., 2011; Hudson et al., 2014), and indeed, the observed pattern of inhibition by both AH-7614 and TUG-1506 can only be explained by an allosteric mode of action. 
Whereas Sparks et al. (2014) more broadly assessed the selectivity of the FFA4 agonist GSK137647A described in their study, they did not extend this to AH-7614. Therefore, having identified TUG-1387 in the current work as a close structural analog of AH-7614 that lacks activity at FFA4, we used each of these ligands to define specific roles for FFA4. Indeed, the FFA4 NAM AH-7614 prevents differentiation of a mouse mesenchymal stem cell line toward an adipocyte phenotype, and does so in a manner that is consistent with blockade of endogenous signaling via FFA4.

We describe AH-7614 and TUG-1506 as the first allosteric ligands for the FFA4 receptor. Despite only a minor structural difference between these two compounds, substantial differences in the nature of their allosterism were observed, perhaps suggesting that further examination of the structure activity relationship within the AH-7614 chemical series may yield novel allosteric FFA4 ligands with diverse pharmacological properties. The fact that the observed NAM properties within the AH-7614 series were clearly probe dependent indicates that care must be taken when designing future studies using these ligands. Overall, with appropriate caution, $\mathrm{AH}-7614$ should prove to be a valuable tool in further unraveling functions of the FFA4 receptor.

\section{Authorship Contributions}

Participated in research design: Watterson, Hudson, Yarwood, Ulven, Milligan.

Conducted experiments: Watterson, Hudson, Alvarez-Curto, Raihan, Dunlop.

Contributed new reagents or analytic tools: Hansen, Azevedo, Martin, Ulven.

Performed data analysis: Watterson, Hudson, Alvarez-Curto.

Wrote or contributed to the writing of the manuscript: Watterson, Hudson, Alvarez-Curto, Milligan.

\section{References}

Alvarez-Curto E, Inoue A, Jenkins L, Raihan SZ, Prihandoko R, Tobin AB, and Milligan G (2016) Targeted elimination of $\mathrm{G}$ proteins and arrestins defines their specific contributions to both intensity and duration of G protein-coupled receptor signaling. J Biol Chem 291: 27147-27159.

Azevedo CM, Watterson KR, Wargent ET, Hansen SV, Hudson BD, Kępczyńska MA, Dunlop J, Shimpukade B, Christiansen E, Milligan G, et al. (2016) Non-acidic free fatty acid receptor 4 agonists with antidiabetic activity. J Med Chem $\mathbf{5 9}$ 8868-8878.

Butcher AJ, Hudson BD, Shimpukade B, Alvarez-Curto E, Prihandoko R, Ulven T, Milligan G, and Tobin AB (2014) Concomitant action of structural elements and receptor phosphorylation determines arrestin-3 interaction with the free fatty acid receptor FFA4. J Biol Chem 289:18451-18465.

Charlton SJ and Vauquelin G (2010) Elusive equilibrium: the challenge of interpreting receptor pharmacology using calcium assays. $\mathrm{Br} J$ Pharmacol 161: $1250-1265$.

Chelliah M, Chu HD, Cox JM, Debenham JS, Eagen K, Lan P, London C, Plotkin MA Shah U, Sinz CJ et al. (2014) Merck Sharp \& Dohme Corporation, assignee. Preparation of substituted spiropiperidinyl compounds useful as GPR120 agonists. WO2014059232A2

Christiansen E, Hansen SV, Urban C, Hudson BD, Wargent ET, Grundmann M Jenkins L, Zaibi M, Stocker CJ, Ullrich S, et al. (2013) Discovery of TUG-770: A highly potent free fatty acid receptor 1 (FFA1/GPR40) agonist for treatment of type 2 diabetes. ACS Med Chem Lett 4:441-445.

Christiansen E, Watterson KR, Stocker CJ, Sokol E, Jenkins L, Simon K, Grundmann M, Petersen RK, Wargent ET, Hudson BD, et al. (2015) Activity of dietary fatty acids on FFA1 and FFA4 and characterisation of pinolenic acid as a dual FFA1/FFA4 agonist with potential effect against metabolic diseases. Br J Nutr 113:1677-1688.

Cornall LM, Mathai ML, Hryciw DH, and McAinch AJ (2014) GPR120 agonism as a countermeasure against metabolic diseases. Drug Discov Today 19:670-679.

Cozzi PG and Zoli L (2008) A rational approach towards the nucleophilic substitutions of alcohols "on water". Angew Chem Int Ed Engl 47:4162-4166.

Davenport AP, Alexander SP, Sharman JL, Pawson AJ, Benson HE, Monaghan AE Liew WC, Mpamhanga CP, Bonner TI, Neubig RR, et al. (2013) International Union of Basic and Clinical Pharmacology. LXXXVIII. G protein-coupled receptor list: recommendations for new pairings with cognate ligands. Pharmacol Rev 65: 967-986.

Gao B, Huang Q, Jie Q, Lu WG, Wang L, Li XJ, Sun Z, Hu YQ, Chen L, Liu BH, et al (2015) GPR120: A bi-potential mediator to modulate the osteogenic and adipogenic differentiation of BMMSCs. Sci Rep 5:14080.
Ghislain J and Poitout V (2017) The role and future of FFA1 as a therapeutic target. Handb Exp Pharmacol 236:159-180.

Gotoh C, Hong YH, Iga T, Hishikawa D, Suzuki Y, Song SH, Choi KC, Adachi T, Hirasawa A, Tsujimoto G, et al. (2007) The regulation of adipogenesis through GPR120. Biochem Biophys Res Commun 354:591-597.

Hansen SV and Ulven T (2017) Pharmacological Tool Compounds for the Free Fatty Acid Receptor 4 (FFA4/GPR120). Handb Exp Pharmacol 236:33-56.

Hasan AU, Ohmori K, Konishi K, Igarashi J, Hashimoto T, Kamitori K, Yamaguchi F, Tsukamoto I, Uyama T, Ishihara Y, et al. (2015) Eicosapentaenoic acid upregulates VEGF-A through both GPR120 and PPAR $\gamma$ mediated pathways in 3T3-L1 adipocytes. Mol Cell Endocrinol 406:10-18.

Hashimoto Y, Kobayashi M, Matsuzaki E, Higashi K, Takahashi-Yanaga F, Takano A, Hirata M, and Nishimura F (2016) Sphingosine-1-phosphateenhanced Wnt5a promotes osteogenic differentiation in C3H10T1/2 cells. Cell Biol Int 40:1129-1136.

Hirasawa A, Tsumaya K, Awaji T, Katsuma S, Adachi T, Yamada M, Sugimoto Y, Miyazaki S, and Tsujimoto G (2005) Free fatty acids regulate gut incretin glucagon-like peptide-1 secretion through GPR120. Nat Med 11:90-94.

Houthuijzen JM (2016) For better or worse: FFAR1 and FFAR4 signaling in cancer and diabetes. Mol Pharmacol 90:738-743.

Houthuijzen JM, Oosterom I, Hudson BD, Hirasawa A, Daenen LG, McLean CM, Hansen SV, van Jaarsveld MT, Peeper DS, Jafari Sadatmand S, Roodhart JM, van de Lest CH, Ulven T, Ishihara K, Milligan G, Voest EE. (2017) Fatty acid 16:4(n-3) stimulates a GPR120-induced signaling cascade in splenic macrophages to promote chemotherapy resistance. FASEB J DOI: 10.1096/fj.201601248R [published ahead of print].

Hudson BD, Christiansen E, Murdoch H, Jenkins L, Hansen AH, Madsen O, Ulven T, and Milligan G (2014) Complex pharmacology of novel allosteric free fatty acid 3 receptor ligands. Mol Pharmacol 86:200-210.

Hudson BD, Shimpukade B, Mackenzie AE, Butcher AJ, Pediani JD, Christiansen E, Heathcote H, Tobin AB, Ulven T, and Milligan G (2013) The pharmacology of TUG891 , a potent and selective agonist of the free fatty acid receptor 4 (FFA4/GPR120), demonstrates both potential opportunity and possible challenges to therapeutic agonism. Mol Pharmacol 84:710-725.

Ichimura A, Hirasawa A, Poulain-Godefroy O, Bonnefond A, Hara T, Yengo L, Kimura I, Leloire A, Liu N, Iida K, et al. (2012) Dysfunction of lipid sensor GPR120 leads to obesity in both mouse and human. Nature 483:350-354.

Lee MN, Kim JW, Oh SH, Jeong BC, Hwang YC, and Koh JT (2016) FGF2 stimulates COUP-TFII expression via the MEK1/2 pathway to inhibit osteoblast differentiation in C3H10T1/2 cells. PLoS One 11:e0159234.

Li Z, Qiu Q, Geng X, Yang J, Huang W, and Qian H (2016) Free fatty acid receptor agonists for the treatment of type 2 diabetes: drugs in preclinical to phase II clinical development. Expert Opin Investig Drugs 25:871-890.

Liu HD, Wang WB, Xu ZG, Liu CH, He DF, Du LP, Li MY, Yu X, and Sun JP (2015) FFA4 receptor (GPR120): A hot target for the development of anti-diabetic therapies. Eur J Pharmacol 763:160-168.

Liu Y, Guan X, Wong EL-M, Liu P, Huang J-S, and Che C-M (2013) Nonheme ironmediated amination of $\mathrm{C}\left(\mathrm{sp}^{3}\right)-\mathrm{H}$ bonds. Quinquepyridine-supported iron-imide/ nitrene intermediates by experimental studies and DFT calculations. J Am Chem Soc 135:7194-7204.

May LT, Leach K, Sexton PM, and Christopoulos A (2007) Allosteric modulation of G protein-coupled receptors. Annu Rev Pharmacol Toxicol 47:1-51.

Milligan G, Alvarez-Curto E, Watterson KR, Ulven T, and Hudson BD (2015) Characterizing pharmacological ligands to study the long-chain fatty acid receptors GPR40/FFA1 and GPR120/FFA4. Br J Pharmacol 172:3254-3265.

Milligan G, Shimpukade B, Ulven T, and Hudson BD (2017) Complex Pharmacology of Free Fatty Acid Receptors. Chem Rev 117:67-110.

Mo XL, Wei HK, Peng J, and Tao YX (2013) Free fatty acid receptor GPR120 and pathogenesis of obesity and type 2 diabetes mellitus. Prog Mol Biol Transl Sci 114: 251-276.

Mohammad S (2016) GPR40 agonists for the treatment of type 2 diabetes mellitus: benefits and challenges. Curr Drug Targets 17:1292-1300.

Moniri NH (2016) Free-fatty acid receptor-4 (GPR120): Cellular and molecular function and its role in metabolic disorders. Biochem Pharmacol 110-111:1-15.

Moran BM, Flatt PR, and McKillop AM (2016) G protein-coupled receptors: signalling and regulation by lipid agonists for improved glucose homoeostasis. Acta Diabetol 53:177-188.

Oh DY, Talukdar S, Bae EJ, Imamura T, Morinaga H, Fan W, Li P, Lu WJ, Watkins SM, and Olefsky JM (2010) GPR120 is an omega-3 fatty acid receptor mediating potent anti-inflammatory and insulin-sensitizing effects. Cell 142: $687-698$.

Oh DY, Walenta E, Akiyama TE, Lagakos WS, Lackey D, Pessentheiner AR, Sasik R, Hah N, Chi TJ, Cox JM, et al. (2014) A Gpr120-selective agonist improves insulin resistance and chronic inflammation in obese mice. Nat Med 20:942-947.

Patrick TB and Dolan JG (1973) Nitrosation of 9-acylamidoxanthines. J Org Chem 38:2828-2830.

Prihandoko R, Alvarez-Curto E, Hudson BD, Butcher AJ, Ulven T, Miller AM, Tobin $\mathrm{AB}$, and Milligan G (2016) Distinct phosphorylation clusters determine the signaling outcome of free fatty acid receptor 4/G Protein-Coupled Receptor 120. Mol Pharmacol 89:505-520.

Quesada-López T, Cereijo R, Turatsinze JV, Planavila A, Cairó M, Gavaldà-Navarro A, Peyrou M, Moure R, Iglesias R, Giralt M, et al. (2016) The lipid sensor GPR120 promotes brown fat activation and FGF21 release from adipocytes. Nat Commun 7: 13479 .

Shimpukade B, Hudson BD, Hovgaard CK, Milligan G, and Ulven T (2012) Discovery of a potent and selective GPR120 agonist. J Med Chem 55:4511-4515.

Song T, Zhou Y, Peng J, Tao YX, Yang Y, Xu T, Peng J, Ren J, Xiang Q, and Wei H (2016) GPR120 promotes adipogenesis through intracellular calcium and extracellular signal-regulated kinase 1/2 signal pathway. Mol Cell Endocrinol 434:1-13. 
Sparks SM, Chen G, Collins JL, Danger D, Dock ST, Jayawickreme C, Jenkinson S, Laudeman C, Leesnitzer MA, Liang X, et al. (2014) Identification of diarylsulfonamides as agonists of the free fatty acid receptor 4 (FFA4/GPR120). Bioorg Med Chem Lett 24: $3100-3103$.

Tamura Y, Nishikawa Y, Sumoto K, Ikeda M, Murase M, and Kise M (1977) Organic sulfur compounds. 5. Synthesis and rearrangement of thioxanthene N-(p-tolylsulfonyl)sulfilimine. J Org Chem 42:3226-3229.

Tang QQ, Otto TC, and Lane MD (2004) Commitment of C3H10T1/2 pluripotent stem cells to the adipocyte lineage. Proc Natl Acad Sci USA 101:9607-9611.

Ulven T and Christiansen E (2015) Dietary fatty acids and their potential for controlling metabolic diseases through activation of FFA4/GPR120. Annu Rev Nutr 35 239-263.

Villegas-Comonfort S, Takei Y, Tsujimoto G, Hirasawa A, and García-Sáinz JA (2017) Effects of arachidonic acid on FFA4 receptor: Signaling, phosphorylation and internalization. Prostaglandins Leukot Essent Fatty Acids 117:1-10.

Watterson KR, Hudson BD, Ulven T, and Milligan G (2014) Treatment of type 2 diabetes by free Fatty Acid receptor agonists. Front Endocrinol (Lausanne) 5:137.
Wood MR, Hopkins CR, Brogan JT, Conn PJ, and Lindsley CW (2011) "Molecular switches" on mGluR allosteric ligands that modulate modes of pharmacology. Biochemistry 50:2403-2410.

Xu J, Li Z, Hou Y, and Fang W (2015) Potential mechanisms underlying the Runx2 induced osteogenesis of bone marrow mesenchymal stem cells. Am J Transl Res 7 $2527-2535$

Yuan Z, Li Q, Luo S, Liu Z, Luo D, Zhang B, Zhang D, Rao P, and Xiao J (2016) PPAR $y$ and Wnt signaling in adipogenic and osteogenic differentiation of mesenchymal stem cells. Curr Stem Cell Res Ther 11:216-225.

Zhang D and Leung PS (2014) Potential roles of GPR120 and its agonists in the management of diabetes. Drug Des Devel Ther 8:1013-1027.

Address correspondence to: Graeme Milligan, Centre for Translational Pharmacology, Wolfson Link Building 253, University of Glasgow, Glasgow G128QQ, Scotland, UK. E-mail: Graeme.Milligan@glasgow.ac.uk 